\title{
Influence of dynamic ozone dry deposition on ozone pollution
}

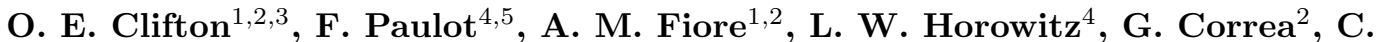 \\ B. Baublitz ${ }^{1,2}$, S. Fares ${ }^{6,7}$, I. Goded ${ }^{8}$, A. H. Goldstein ${ }^{9}$, C. Gruening ${ }^{8}$, A. J. \\ Hogg $^{10}$, B. Loubet ${ }^{11}$, I. Mammarella ${ }^{12}$, J. W. Munger ${ }^{13}$, L. Neil ${ }^{14}$, P. Stella ${ }^{15}$, \\ J. Uddling ${ }^{16}$, T. Vesala ${ }^{12,17}$, E. Weng ${ }^{18,19}$ \\ ${ }^{1}$ Department of Earth and Environmental Sciences, Columbia University, New York, New York, USA \\ ${ }^{2}$ Lamont-Doherty Earth Observatory of Columbia University, Palisades, New York, USA \\ ${ }^{3}$ Advanced Study Program, National Center for Atmospheric Research, Boulder, Colorado, USA \\ ${ }^{4}$ National Oceanic and Atmospheric Administration Geophysical Fluid Dynamics Laboratory, Princeton, \\ New Jersey, USA \\ ${ }^{5}$ Program in Atmospheric and Oceanic Sciences, Princeton University, Princeton, New Jersey, USA \\ ${ }^{6}$ Council of Agricultural Research and Economics, Research Centre of Forestry and Wood, Rome, Italy \\ ${ }^{7}$ National Research Council, Institute of Bioeconomy, Rome, Italy \\ ${ }^{8}$ European Commission, Joint Research Centre, Ispra, Italy \\ ${ }^{9}$ Department of Environmental Science, Policy, and Management, University of California, Berkeley, \\ California, USA \\ ${ }^{10}$ Program in Technical Communication, College of Engineering, University of Michigan, Ann Arbor, \\ Michigan, USA \\ ${ }^{11}$ National Institute for Agronomic Research UMR INRA/AgroParisTech ECOSYS, Université \\ Paris-Saclay, Thiverval-Grignon, France \\ ${ }^{12}$ Institute for Atmospheric and Earth System Research/Physics, University of Helsinki, Helsinki, Finland \\ ${ }^{13}$ School of Engineering and Applied Science and Department of Earth and Planetary Sciences, Harvard \\ University, Cambridge, Massachusetts, USA \\ ${ }^{14}$ Hemmera, an Ausenco company, Ontario, Canada
${ }^{15}$ UMR SAD-APT, AgroParisTech, INRA, Université Paris-Saclay, Paris, France \\ ${ }^{16}$ Department of Biological and Environmental Sciences, University of Gothenburg, Gothenburg, Sweden \\ ${ }^{17}$ Institute for Atmospheric and Earth System Research/Forest Sciences, University of Helsinki, Helsinki, \\ Finland \\ ${ }^{18}$ Center for Climate Systems Research, Columbia University, New York, New York, USA \\ ${ }^{19}$ NASA Goddard Institute for Space Studies, New York, New York, USA
}

\section{Key Points:}

- Remote and local ozone depositional sinks shape regional winter ozone pollution

- Dynamic ozone dry deposition changes summer surface ozone over northern midlatitude regions by -4 to $+7 \mathrm{ppb}$

- Variability and $21^{\text {st }}$-century changes in both stomatal and nonstomatal deposition influence summer surface ozone distributions

This is the author manuscript accepted for publication and has undergone full peer review but has not been through the copyediting, typesetting, pagination and proofreading process, which may learresponfing author: Olivia Clifton oclifton@ucar. edu as doi: 10.1029/2020JD032398 


\begin{abstract}
Identifying the contributions of chemistry and transport to observed ozone pollution using regional-to-global models relies on accurate representation of ozone dry deposition. We use a recently developed configuration of the NOAA GFDL chemistry-climate model - in which the atmosphere and land are coupled through dry deposition - to investigate the influence of ozone dry deposition on ozone pollution over northern mid-latitudes. In our model, deposition pathways are tied to dynamic terrestrial processes, such as photosynthesis and water cycling through the canopy and soil. Small increases in winter deposition due to more process-based representation of snow and deposition to surfaces reduce hemispheric-scale ozone through the lower troposphere by $5-12 \mathrm{ppb}$, improving agreement with observations relative to a simulation with the standard configuration for ozone dry deposition. Declining snow cover by the end of the $21^{\text {st }}$ century tempers the previously identified influence of rising methane on winter ozone. Dynamic dry deposition changes summer surface ozone by -4 to $+7 \mathrm{ppb}$. While previous studies emphasize the importance of uptake by plant stomata, new diagnostic tracking of depositional pathways reveals a widespread impact of nonstomatal deposition on ozone pollution. Daily variability in both stomatal and nonstomatal deposition contribute to daily variability in ozone pollution. $21^{\text {st }}$-century changes in summer deposition result from a balance among changes in individual pathways, reflecting differing responses to both high carbon dioxide (through plant physiology versus biomass accumulation) and water availability. Our findings highlight a need for constraints on the processes driving ozone dry deposition to test representation in regional-to-global models.
\end{abstract}

\title{
1 Introduction
}

In the troposphere, ozone is an air pollutant, a potent greenhouse gas, and an important source of the hydroxyl radical, the main tropospheric oxidant. Regional-to-global atmospheric chemistry models are key tools for quantifying the impacts of ozone pollution on human and vegetation health and pinpointing the drivers of observed trends and variability in tropospheric constituents. Representing ozone sources and sinks accurately in these models is fundamental to their utility. Ozone dry deposition is an important $(20 \%$ of the annual global tropospheric loss), but uncertain and frequently overlooked, tropospheric ozone sink (Wild, 2007; Hardacre et al., 2015). Here we investigate the role of ozone dry deposition on ozone pollution at northern mid-latitudes with a global chemistryclimate model that leverages the carbon and water cycling in its underlying dynamic vegetation land model for representing dry deposition.

Dry deposition of ozone occurs through surface-mediated reactions after diffusion through plant stomata, or on leaf cuticles, other plant material, soil, water and snow. Ozone deposition velocity (a measure of the efficiency of the removal independent from ambient ozone concentration) is typically highest during summer, reflecting uptake by vegetation. Winter ozone dry deposition is usually not a research focus due to relatively low ozone deposition velocity. However, the long winter ozone lifetime implies efficient transport through large-scale circulation patterns, such that ozone at any particular location depends on both local and remote sources and sinks and thus may be sensitive to changes in ozone dry deposition locally and upwind. Although previous studies examine the sensitivity of winter ozone to ozone deposition velocity over the Uintah basin in the western United States (Matichuk et al., 2017) and boreal and Arctic regions (Helmig et al., 2007), it is unknown how ozone dry deposition impacts large-scale winter ozone over northern mid-latitudes. While ozone pollution is typically regarded as a summer problem (at least over polluted and populated regions), projected changes in anthropogenic precursor emissions drive large $21^{\text {st }}$-century increases in winter ozone (Clifton et al., 2014; Gao et al., 2013; Rieder et al., 2018), implying a need to advance understanding of winter ozone sources and sinks. 
Much of the attention around ozone dry deposition is on its influence on summer ozone pollution. Previous work examines changes in ozone dry deposition with environmental conditions, ambient carbon dioxide, and land use/land cover as well as the impact of dry deposition on summer surface ozone (Solberg et al., 2008; Andersson \& Engardt, 2010; Ganzeveld et al., 2010; S. Wu et al., 2012; Trail et al., 2015; Fu \& Tai, 2015; Huang et al., 2016; Geddes et al., 2016; Hollaway et al., 2016; Heald \& Geddes, 2016; Anav et al., 2018; M. Lin et al., 2019; Wong et al., 2019). The aforementioned analyses linking surface ozone with ozone dry deposition all rely on models. These models typically assume that stomatal uptake dominates ozone dry deposition and that nonstomatal deposition is roughly constant or simply varies with leaf area index. However, laboratory and field evidence suggests that these assumptions may limit our ability to model ozone dry deposition accurately (Fuentes et al., 1992; Massman, 2004; Altimir et al., 2006; Cieslik, 2009; Fowler et al., 2009; Fares et al., 2010, 2012, 2014; Rannik et al., 2012; Potier et al., 2015, 2017; Sun et al., 2016; Clifton et al., 2017; Fumagalli et al., 2016; Clifton et al., 2019; Stella, Loubet, et al., 2011). Current understanding of nonstomatal deposition pathways is that leaf cuticular uptake increases with leaf wetness, soil uptake decreases with soil moisture, and snow on vegetation and the ground decreases uptake (Clifton et al., 2020). Systematic omissions in process representation that lead to variations in ozone deposition velocity with meteorology or biophysics may impede accurate model simulations of changes in ozone pollution attributable to changes in dry deposition.

Here we probe the influence of ozone dry deposition on winter and summer ozone pollution over northern mid-latitudes under a $21^{\text {st }}$-century scenario for climate and anthropogenic precursor emissions using a new configuration of the global National Oceanic and Atmospheric Administration (NOAA) Geophysical Fluid Dynamics Laboratory (GFDL) chemistry-climate model. In particular, we use the biophysics of the land component to simulate ozone dry deposition by plant stomata, stems, and wet, dry, and snow-covered soil and leaf cuticles. We evaluate this model with ozone eddy covariance flux observations from long-term and short-term datasets and estimates of the stomatal fraction of ozone dry deposition derived from observations. We compare simulations with this new dynamic ozone dry deposition scheme to simulations using a prescribed climatology of ozone deposition velocity, the default configuration in the GFDL model. While nonstomatal deposition pathways represent observed dependencies on meteorological and biophysical variables in our model to the extent possible, these pathways remain uncertain due to a paucity of observational constraints, and their representation in models is highly parameterized (Clifton et al., 2020). Our goal is to investigate how dynamic ozone dry deposition, based on current understanding, influences ozone pollution.

\section{Methods}

We conduct time-slice simulations for the 2010s and 2090s with the NOAA GFDL atmospheric model version 3 (AM3) coupled to the NOAA GFDL land model version 3 (LM3) through not only carbon, water, and energy exchanges but also dry deposition of several atmospheric constituents (AM3DD) (Paulot et al., 2018). Each simulation contains ten years. Below we describe the model configuration and the dynamic dry deposition scheme for ozone, which we modify from the general dynamic dry deposition scheme described by Paulot et al. (2018).

AM3 is a chemistry-climate model with online fully coupled stratospheric and tropospheric chemistry (Naik et al., 2013; Donner et al., 2011). We use AM3 with C48 (cubed sphere) configuration (approximately $2^{\circ}$ by $2^{\circ}$ ) and 48 vertical levels. We update the treatment of wet deposition of aerosols and gases in AM3 following Paulot et al. (2016); in particular, snow formed by the Bergeron process does not scavenge water-soluble aerosols.

We use Representative Concentration Pathway 8.5 (RCP8.5) (van Vuuren et al., 2011; Riahi et al., 2011; Lamarque et al., 2011), the high-warming scenario designed for 
the Coupled Model Intercomparison Project 5 , to represent $21^{\text {st }}$-century climate and anthropogenic emissions. Aerosol and ozone precursor emissions and global concentrations of greenhouse gases are set to 2010 and 2090 levels for our 2010s and 2090s time-slice simulations, respectively. Isoprene emissions are calculated online with a version of Model of Emissions of Gases and Aerosols from Nature (MEGAN) in AM3 (Guenther et al., 2006; Emmons et al., 2010; Rasmussen et al., 2012). Simulations are forced with decadal mean (2011-2020 or 2091-2100) sea ice and sea-surface temperatures from transient RCP8.5 simulations (average over three ensemble members) from the NOAA GFDL coupled model version 3. We use initial conditions for 2010 and 2090 from one ensemble member of the transient $21^{\text {st }}$-century RCP8.5 simulations described in Clifton et al. (2014) that were spun up from a pre-industrial control simulation (John et al., 2012).

LM3 is a global land model with terrestrial carbon, energy and water cycling, dynamic vegetation, and land use transitions (Shevliakova et al., 2009; Milly et al., 2014). A sub-grid tiling framework in LM3 allows individual tiles to represent distinct land uses, including primary vegetation, cropland, pasture, secondary vegetation, as well as bodies of water and glaciers. We prescribe land use distributions with either 2010 or 2090 RCP8.5 (Hurtt et al., 2011). Primary vegetation has never been disturbed by humans directly, whereas secondary vegetation has been harvested and subsequently abandoned at least once. Each grid cell contains up to twelve stages of secondary vegetation, allowing for differing recovery times. Modifications to crop harvesting and pasture grazing follow Paulot et al. (2018). Each vegetated sub-grid tile has one land cover type. Land cover types include temperate deciduous forests, tropical forests, coniferous forests, $\mathrm{C}_{3}$ grass, and $\mathrm{C}_{4}$ grass. The distribution of vegetation evolves with climate, but the distribution of bodies of water and glaciers is time invariant. There are five pools of vegetation biomass (leaves, fine roots, sapwood, heartwood, and labile stores), and allocation rules and daily net primary production update the pools each day (Shevliakova et al., 2009). Phenology (i.e., leaf on/off) and thus leaf area index (LAI) is updated monthly from the leaf biomass pool according to monthly mean air temperature and soil water available to the plant (Shevliakova et al., 2009) except for temperate deciduous vegetation, for which LAI has strong seasonality. We update the temperate deciduous vegetation daily according to critical temperature and growing degree day following Weng et al. (2015).

\subsection{Ozone dry deposition in AM3DD}

The new ozone dry deposition parameterization in LM3 uses a big-leaf resistance framework. Pathways for ozone dry deposition include leaf cuticles, stomata, stems, and the ground. Ozone deposition velocity $\left(\mathrm{v}_{d}\right)\left[\mathrm{cm} \mathrm{s}^{-1}\right]$ follows:

$$
v_{d}=\left[R_{a}+\frac{1}{\frac{1}{R_{b, v}+\frac{1}{\frac{1}{R_{\text {cut }}}+\frac{1}{R_{\text {stom }}+R_{\text {meso }}}}}+\frac{1}{R_{b, v}+R_{\text {stem }}}+\frac{1}{R_{a c, g}+R_{b, g}+R_{g}}}\right]^{-1} * 100
$$

In the following paragraphs, we define each resistance term in equation 1 . The scheme follows Paulot et al. (2018) except where otherwise noted.

The resistance to turbulent transport between the atmosphere and canopy $\left(\mathrm{R}_{a}\right)$ $\left[\mathrm{s} \mathrm{m}^{-1}\right]$ follows Fick's Law and Monin-Obukhov Similarity Theory. The quasi-laminar boundary-layer resistance for vegetation $\left(\mathrm{R}_{b, v}\right)\left[\mathrm{s} \mathrm{m}^{-1}\right]$ follows Choudhury and Monteith (1988):

$$
R_{b, v}=\frac{a}{b} \sqrt{\frac{d_{l e a f}}{u_{h}}}\left[1-e^{-a / 2}\right]\left(\frac{S c}{P r}\right)^{2 / 3}
$$

$\mathrm{d}_{\text {leaf }}$ is the leaf dimension $[\mathrm{m}] ; \mathrm{u}_{h}$ is wind speed at the top of the canopy $\left[\mathrm{m} \mathrm{s}^{-1}\right]$ ( $\mathrm{h}$ is canopy height $[\mathrm{m}]$ ); $\mathrm{a}$ is an empirical constant (value of 3 ); $\mathrm{b}\left[\mathrm{m} \mathrm{s}^{-0.5}\right]$ is an empirical constant (value of 0.02); Sc is the Schmidt number [unitless]; Pr is the Prandtl number 
[unitless]. $\mathrm{R}_{b, v}$ is scaled by fraction of vegetation that is stems versus leaves when used in equation 1 .

Paulot et al. (2018) apply both equation 2 and the Jensen and Hummelsh $\varnothing \mathbf{j}$ (1995, 1997) $\mathrm{R}_{b, v}$ parameterization, with the intention of including a resistance to in-canopy turbulence. However, equation 2 is a quasi-laminar boundary-layer resistance, not a resistance to in-canopy turbulence. We use equation 2 for $\mathrm{R}_{b, v}$ because it is used for energy and carbon exchanges in LM3. A resistance to in-canopy turbulence for leaf deposition is unnecessary in our big-leaf model because $\mathrm{R}_{a}$ accounts for turbulent transport between the atmosphere and canopy and all vegetation is assumed to be at the canopy height.

We distinguish cuticular deposition among dry, wet, and snow-covered leaves. Fractional leaf wetness is calculated from canopy-intercepted water, specifically the ratio of canopy-intercepted water to the maximum storage capacity to the two-thirds power (Bonan, 1996). Fractional snow cover on vegetation is calculated in the same way but with canopyintercepted snow. We employ an adjustment function s [unitless] to reduce wet and dry cuticular deposition when leaf temperatures are cold $\left(<5^{\circ} \mathrm{C}\right)$.

$$
s\left(T_{\text {leaf }}\right)=\max \left[e^{-c\left(T_{\text {leaf }}-5\right)}, 1\right]
$$

$\mathrm{T}_{\text {leaf }}$ is leaf temperature $\left[{ }^{\circ} \mathrm{C}\right]$; c is a constant $\left[{ }^{\circ} \mathrm{C}^{-1}\right]$. Such an adjustment function assumes that the chemistry on surfaces is slower when the surfaces are cold. We use $\mathrm{c}=0.9$ ${ }^{\circ} \mathrm{C}^{-1}$ for wet and $\mathrm{c}=0.1^{\circ} \mathrm{C}^{-1}$ for dry cuticular deposition, employing different values because the initial resistances for wet and dry cuticular deposition differ by an order of magnitude (see below). Our temperature adjustment function, an adaptation of Zhang et al. (2003), allows for cuticular deposition at cold temperatures to be reduced, but not turned off. We do not turn off cuticular deposition on cold surfaces following observational evidence that uptake occurs on material protruding from snow (Clifton et al., 2020).

Paulot et al. (2018) use the Zhang et al. (2003) temperature adjustment function. Without our change to the Zhang et al. (2003) temperature adjustment function, winter cuticular uptake to coniferous forests (only in boreal regions in LM3) becomes higher than supported by field observations. For example, simulated winter mean $\mathrm{v}_{d}$ over boreal regions $\left(55-65^{\circ} \mathrm{N}\right)$ with LAI $\geq 2 \mathrm{~m}^{2} \mathrm{~m}^{-2}$ is $0.1 \mathrm{~cm}^{-1}$ with this temperature adjustment function, only slightly less than observations from Hyytiälä, a boreal coniferous forest, which suggest a winter mean $\mathrm{v}_{d}$ of $0.12 \mathrm{~cm} \mathrm{~s}^{-1}$. Previous studies do not identify the need for a stronger temperature adjustment function, likely because they assume winter boreal regions are completely snow-covered, whereas here we consider dynamic canopy cycling of snow. Canopy snow cycling in LM3 allows conifers to be occasionally snowfree, leading us to implement a stronger temperature adjustment function to reduce otherwise unrealistically high simulated uptake to bare conifer cuticles.

The resistance to cuticular deposition to dry leaves $\left(\mathrm{R}_{c u t, d r y}\right)\left[\mathrm{s} \mathrm{m}^{-1}\right]$ follows:

$$
R_{c u t, d r y}=\frac{R_{i, c u t, d r y}}{L A I e^{R H}} s\left(T_{\text {leaf }}\right)
$$

$\mathrm{R}_{i, c u t, d r y}$ is the initial resistance to dry cuticular deposition $\left[\mathrm{s} \mathrm{m}^{-1}\right] ; \mathrm{RH}$ is fractional incanopy relative humidity [unitless]. The RH dependence is an update to Paulot et al. (2018) and follows field and laboratory evidence suggesting that ozone dry deposition to cuticles occurs through aqueous surface-mediated chemistry (Fuentes et al., 1992; Zhang et al., 2002; Potier et al., 2015, 2017; Sun et al., 2016). In particular, the RH dependence in the model for $\mathrm{R}_{c u t, d r y}$ represents the thin water films that form on leaves at high ambient humidity (Burkhardt \& Hunsche, 2013).

Higher ozone deposition to leaves wet by rain and dew (Clifton et al., 2020) is also accounted for in our model. The resistance to cuticular deposition to leaves wet by rain 
and dew $\left(\mathrm{R}_{\text {cut }, w e t}\right)\left[\mathrm{s} \mathrm{m}^{-1}\right]$ follows:

$$
R_{\text {cut }, \text { wet }}=\frac{R_{i, c u t, w e t}}{L A I} s\left(T_{\text {leaf }}\right)
$$

$\mathrm{R}_{i, c u t, w e t}$ is the initial resistance to wet cuticular deposition $\left[\mathrm{s} \mathrm{m}^{-1}\right]$. For pastures, crops, and grasses, $\mathrm{R}_{i, c u t, d r y}$ is $4000 \mathrm{~s} \mathrm{~m}^{-1}$ and $\mathrm{R}_{i, c u t, \text { wet }}$ is $200 \mathrm{~s} \mathrm{~m}^{-1}$ and for coniferous, temperate deciduous, and tropical trees, $\mathrm{R}_{i, c u t, d r y}$ is $6000 \mathrm{~s} \mathrm{~m}^{-1}$ and $\mathrm{R}_{i, c u t, w e t}$ is $400 \mathrm{~s} \mathrm{~m}^{-1}$. Initial resistances follow Zhang et al. (2003), except that initial resistances for coniferous trees are the same for other trees, not much lower as suggested by Zhang et al. (2003). Paulot et al. (2018) originally implemented the initial resistances suggested by Zhang et al. (2003) for conifers, but increasing the initial resistances for conifers to agree with the values for other trees reduces dry deposition to coniferous forests (only in boreal regions in LM3) where LM3 overestimates LAI. We note that the Zhang et al. (2003) initial resistances were derived from observations from one growing season or less in eastern U.S. locations and thus their application more generally for global land use types is highly uncertain. follows:

The resistance to cuticular deposition to snow-covered leaves $\left(\mathrm{R}_{\text {cut,snow }}\right)\left[\mathrm{s} \mathrm{m}^{-1}\right]$

$$
R_{\text {cut }, \text { snow }}=\frac{R_{i, \text { snow }}}{L A I}
$$

$\mathrm{R}_{i, \text { snow }}$, the initial resistance to snow, is $7000 \mathrm{~s} \mathrm{~m}^{-1}$. Often the number of surfaces covered by snow is not considered in models of ozone dry deposition (i.e., $\mathrm{R}_{\text {cut,snow }}=\mathrm{R}_{i, \text { snow }}$ ). Our model (equation 6) assumes deposition increases with LAI $\left[\mathrm{m}^{2} \mathrm{~m}^{-2}\right]$, implying more deposition with a larger surface area covered with snow. This relationship is supported by observations of relatively high $\mathrm{v}_{d}$ over snow-covered forests (Padro et al., 1992; Padro, 1993; Z. Wu et al., 2016; Neirynck \& Verstraeten, 2018).

Our value for $\mathrm{R}_{i, \text { snow }}$ is more than triple the $2000 \mathrm{~s} \mathrm{~m}^{-1}$ used by Paulot et al. (2018) and given by Zhang et al. (2003). Increasing $\mathrm{R}_{i, \text { snow }}$ leads to uptake by snow on the ground and leaf cuticles of $0.015 \mathrm{~cm} \mathrm{~s}^{-1}$ on average over $40-65^{\circ} \mathrm{N}$ for present-day winter, agreeing with most field and laboratory observations supporting $\mathrm{v}_{d}$ for snow-covered regions higher than $0.01 \mathrm{~cm} \mathrm{~s}^{-1}$ (Aldaz, 1969; Colbeck \& Harrison, 1985; I. Galbally \& Allison, 1972; I. E. Galbally \& Roy, 1980; Wesely et al., 1981; Stocker et al., 1995; Gong et al., 1997; Hopper et al., 1998; Helmig et al., 2009; Clifton et al., 2020).

Stomatal resistance $\left(\mathrm{R}_{\text {stom }}\right)$ [ $\left.\mathrm{s} \mathrm{m}^{-1}\right]$ is calculated explicitly from net photosynthesis $\left(\mathrm{A}_{n e t}\right)\left[\mathrm{mol} \mathrm{CO}_{2} \mathrm{~m}^{-2} \mathrm{~s}^{-1}\right.$ ] (Farquhar et al., 1980; Collatz et al., 1991, 1992) via Leuning (1995):

$$
R_{\text {stom }}=\frac{p_{s}}{R T_{\text {leaf }}} \frac{1}{m}\left(1+\frac{d_{s}}{d_{0}}\right) \frac{c_{i}-\Gamma}{A_{\text {net }}} L A I
$$

$\mathrm{p}_{s}$ is surface pressure $[\mathrm{Pa}] ; \mathrm{R}$ is the universal gas constant $\left[\mathrm{J}\right.$ mol air $\left.{ }^{-1} \mathrm{~K}^{-1}\right] ; \mathrm{m}$ is an empirical constant [unitless]; $\mathrm{d}_{s}$ is the humidity deficit $\left[\mathrm{kg} \mathrm{H}_{2} \mathrm{O} \mathrm{kg} \mathrm{air}{ }^{-1}\right.$ ]; $\mathrm{d}_{0}$ is another empirical constant $\left[\mathrm{kg} \mathrm{H}_{2} \mathrm{O} \mathrm{kg} \mathrm{air}{ }^{-1}\right] ; \mathrm{c}_{i}$ is carbon dioxide concentration internal to the leaf $\left[\mathrm{mol} \mathrm{CO} \mathrm{Col} \mathrm{air}^{-1}\right] ; \Gamma$ is carbon dioxide compensation point $\left[\mathrm{mol} \mathrm{CO} \mathrm{mol} \mathrm{air}^{-1}\right] ; \mathrm{R}_{\text {stom }}$ shown in the above equation is also scaled by the inverse of the fractional water stress if the fractional water stress $<1$ (Milly et al., 2014). The water stress is the ratio of water supply to roots to water demand from atmosphere.

We account for the different diffusivities of ozone and water vapor by scaling $\mathrm{R}_{\text {stom }}$ given in equation 7 for water vapor by the ratio of the diffusivities of the two gases. The resistance to ozone reacting with internal fluids and tissues in our model (i.e., often called a mesophyll resistance, or $\left.\mathrm{R}_{\text {meso }}\left[\mathrm{s} \mathrm{m}^{-1}\right]\right)$ is small $\left(0.01 \mathrm{~s} \mathrm{~m}^{-1}\right)$ because laboratory evidence suggests that ozone reacts immediately upon entering stomata (Laisk et al., 1989; D. Wang et al., 1995).

Stomatal deposition is reduced on the part of the leaf that is wet by dew or rain; this happens through a $30 \%$ decrease in $\mathrm{A}_{\text {net }}$ and stomatal conductance on the wet part 
of the leaf. This is a correction to Paulot et al. (2018) and M. Lin et al. (2019) who reduce stomatal deposition by the fraction of the leaf that is wet in addition to the $30 \%$ decrease in $\mathrm{A}_{n e t}$ and stomatal conductance that we retain here.

The stem resistance $\left(\mathrm{R}_{\text {stem }}\right)$ to ozone dry deposition is:

$$
R_{\text {stem }}=\frac{R_{i, \text { stem }}}{S A I}
$$

$\mathrm{R}_{i, \text { stem }}$ is $3000 \mathrm{~s} \mathrm{~m}^{-1}$; $\mathrm{SAI}\left[\mathrm{m}^{2} \mathrm{~m}^{-2}\right]$ is stem area index. While Paulot et al. (2018) use $4000 \mathrm{~s} \mathrm{~m}^{-1}$ and the Zhang et al. (2003) temperature adjustment function to reduce stem deposition onto cold surfaces, our change to $\mathrm{R}_{i, \text { stem }}$ and removal of the temperature adjustment function allow for higher deposition to stems and distinguishing between winter deposition to vegetated versus non-vegetated regions (Clifton et al., 2020). The latter also allows for slightly higher winter deposition to bare deciduous trees relative to areas without woody biomass, as supported by observations (Padro et al., 1992; Clifton et al., 2020).

A resistance to in-canopy turbulence influences dry deposition to the ground when vegetation is present (LAI+SAI $>0.25 \mathrm{~m}^{2} \mathrm{~m}^{-2}$ ) and follows Paulot et al. (2018). The model was developed from a very short-term regression analysis over a corn field (Van Pul \& Jacobs, 1994), but has been used widely in dry deposition schemes (Erisman et al., 1994; Zhang et al., 2002; Emberson et al., 2000; Pleim \& Ran, 2011). We use this $\mathrm{R}_{a c, g}$ parameterization because there are not many alternatives for large-scale big-leaf modeling.

$$
R_{a c, g}=\frac{14(L A I+S A I) h}{u_{*}}
$$

$\mathrm{u}_{*}$ is friction velocity $\left[\mathrm{m} \mathrm{s}^{-1}\right]$. The number 14 is a constant fit via regression and has units of $\mathrm{m}^{-1}$. Instead of setting LAI to unity when trees are leafless as Erisman et al. (1994) do, we replace LAI with $\mathrm{LAI}+\mathrm{SAI}$ for all conditions. If vegetation is not present, $\mathrm{R}_{a c, g}$ is negligible $\left(0.01 \mathrm{~s} \mathrm{~m}^{-1}\right)$.

The quasi-laminar boundary-layer resistance for all ground surfaces $\left(\mathrm{R}_{b, g}\right)\left[\mathrm{s} \mathrm{m}^{-1}\right]$ except lakes follows Wesely and Hicks (1977) implemented by Paulot et al. (2018):

$$
R_{b, g}=\frac{2}{k u_{*}}\left(\frac{S c}{P r}\right)^{2 / 3}
$$

$\mathrm{k}$ is the von Kármán constant [unitless]. If vegetation is present then $\mathrm{u}_{*}$ near the ground $\left(u_{*, g}\right)\left[\mathrm{m} \mathrm{s}^{-1}\right]$ is used in equation 10 .

$$
u_{*, g}=u_{*} e^{0.6(L A I+S A I)\left(\frac{z 0, g}{h}-1\right)}
$$

$\mathrm{z}_{0, g}$ is the roughness length of the ground for scalars [m] as calculated in Bonan (1996). Equation 11 follows Loubet et al. (2006) but also includes SAI, allowing bare trees to contribute to drag. For very low vegetation $(\mathrm{h}<0.1 \mathrm{~m})$, we assume $\mathrm{u}_{*, g}=\mathrm{u}_{*}$.

The quasi-laminar boundary-layer resistance for lakes $\left(\mathrm{R}_{b, g, l a k e}\right)\left[\mathrm{s} \mathrm{m}^{-1}\right]$ follows Hicks and Liss (1976):

$$
R_{b, g, \text { lake }}=\frac{\ln \left(\frac{z_{0, g}}{D_{O_{3}} k u_{*}}\right)}{k u_{*}}
$$

$\mathrm{D}_{\mathrm{O}_{3}}$ is the diffusivity of ozone in air $\left[\mathrm{m}^{2} \mathrm{~s}^{-1}\right]$.

We distinguish dry deposition to the ground among snow-covered, wet, and dry soil, deserts, lakes, and glaciers. While a synthesis across observations suggests ground deposition depends on soil moisture (Massman, 2004), the exact relationship is unknown. We thus prescribe a simple step function such that ground uptake decreases when soil 
is wet as suggested by Massman (2004). We define wet soil as fractional surface soil moisture in a tile $>0.9$. Some work points to an exponential or logarithmic dependence of ground deposition with moisture (Stella, Loubet, et al., 2011; Stella et al., 2019; Fumagalli et al., 2016), but we maintain a simpler change in ground deposition due to poor understanding of what happens at the large scale.

The treatment of ground deposition to cold surfaces from Paulot et al. (2018) considers the ground to be covered with snow if there is any snow in a tile and employs the Zhang et al. (2003) temperature adjustment function to reduce ground deposition at cold temperatures. Instead, we update the model to use fractional snow cover on the ground, calculated as a function of snow depth and prescribed critical depth as done for surface albedo. We change the temperature adjustment function to the one used for cuticles (equation 3) and use $\mathrm{c}=0.025^{\circ} \mathrm{C}^{-1}$ and soil temperature $\left(\mathrm{T}_{\text {soil }}\right)\left[{ }^{\circ} \mathrm{C}\right]$. We maintain the Paulot et al. (2018) treatment of frozen lakes: lakes are frozen if there is any solid water.

The resistance to ground deposition $\left(\mathrm{R}_{g}\right)\left[\mathrm{s} \mathrm{m}^{-1}\right]$ follows:

$$
R_{g}=R_{i, g} s\left(T_{\text {soil }}\right)
$$

$\mathrm{R}_{i, g}\left[\mathrm{~s} \mathrm{~m}^{-1}\right]$ is the initial resistance to ground deposition. $\mathrm{R}_{i, g}$ for snow and ice is $\mathrm{R}_{i, \text { snow }}$ $\left(7000 \mathrm{~s} \mathrm{~m}^{-1}\right)$. $\mathrm{R}_{i, g}$ for wet surfaces (e.g., lakes, wet soil) is $500 \mathrm{~s} \mathrm{~m}^{-1}$ and dry vegetated surfaces is $200 \mathrm{~s} \mathrm{~m}^{-1}$ (Zhang et al., 2003). $\mathrm{R}_{i, g}$ for deserts (defined by $<0.05 \mathrm{~kg} \mathrm{~m}^{-2}$ biomass) is $500 \mathrm{~s} \mathrm{~m}^{-1}$. Ozone dry deposition to the ground is largely considered to occur through reaction with soil organic material, but short-term observations suggest non-negligible uptake over the Sahara Desert (Güsten et al., 1996). However, relationships between soil organic content and ozone dry deposition to the ground are poorly constrained, leading to major uncertainties in representing dry deposition in different dry environments. Paulot et al. (2018) define $\mathrm{R}_{i, g}$ for deserts to be $500 \mathrm{~s} \mathrm{~m}^{-1}$, but their desert definition is broader $\left(<0.25 \mathrm{~kg} \mathrm{~m}^{-2}\right.$ biomass). Our changes to ground deposition to deserts in part reflect the need for non-negligible deposition in regions such as the western US where otherwise $\mathrm{v}_{d}$ in LM3 is too low due to inaccurate representation of vegetation there.

In order to probe the contribution of different deposition pathways to $\mathrm{v}_{d}$, we examine effective conductances. Generally, a conductance is the inverse of a resistance. The effective conductance is the amount of deposition (in velocity units) occurring through a given deposition pathway. The sum of all of the effective conductances is $\mathrm{v}_{d}$.

Dry deposition to the ocean in AM3DD follows monthly average fields from GEOSChem, a widely used chemical transport model. Aside from the meteorological dependencies of the resistances to turbulent transport and the quasi-laminar boundary layer between the ocean and atmosphere, $\mathrm{v}_{d}$ in GEOS-Chem over oceans does not change with meteorology, sea-surface temperatures, or surface-mediated chemistry in contrast to observational evidence (Ganzeveld et al., 2009; Martino et al., 2012; Helmig et al., 2012; Sarwar et al., 2016; Luhar et al., 2017).

\subsection{Sensitivity simulation with default configuration for ozone dry de- position}

In addition to AM3DD simulations with dynamic ozone dry deposition, we examine AM3DD simulations where we prescribe a monthly mean climatology of $\mathrm{v}_{d}$ scaled to a diel cycle (hereafter, AM3DD-staticO3DD), which is the default configuration for the GFDL model (Naik et al., 2013; Paulot et al., 2016). The climatology is single-year monthly average fields from a widely used chemical transport model, GEOS-Chem. We impose the multiyear monthly mean diel cycle from AM3DD 2010s so that differences between AM3DD and AM3DD-staticO3DD reflect differences in interannual, daily, and spatial variability and $21^{\text {st }}$-century changes in $\mathrm{v}_{d}$ rather than the diel cycle. AM3DDstaticO3DD for the 2090s uses the same setup for $\mathrm{v}_{d}$ as AM3DD-staticO3DD for the 2010s, 
which allows us to consider how neglecting $21^{s t}$-century changes in $\mathrm{v}_{d}$ impacts surface ozone projections.

Briefly, the $\mathrm{v}_{d}$ climatology was generated with GEOS-Chem, which uses a modified Wesely (1989) dry deposition scheme (Y. Wang et al., 1998). $\mathrm{R}_{a}$ follows Fick's Law and Monin-Obukhov Similarity Theory (specifically, Businger et al. (1971)) and $\mathrm{R}_{b}$ follows Wesely and Hicks (1977). $\mathrm{R}_{g}$ and $\mathrm{R}_{a c, g}$ are time-invariant, but change with land cover type. Ozone dry deposition to cuticles varies with LAI and land cover type. Land cover type follows the Olson et al. (2001) land map. Stomatal ozone dry deposition varies with LAI, light, temperature, and land cover type (Y. Wang et al., 1998). This scheme also has a deposition pathway to the ground as well as to the lower canopy. High albedo $(>0.4)$ is used as a proxy for snow-covered surfaces to which ozone dry deposition is inhibited. The temperature adjustment function for cold surfaces in GEOS-Chem follows Wesely (1989).

\section{Model evaluation of dynamic ozone dry deposition}

We compare monthly mean $\mathrm{v}_{d}$ from ozone eddy covariance fluxes at observational sites (Table 1) with $\mathrm{v}_{d}$ simulated by AM3DD (Figures 1,2). We archive simulated $\mathrm{v}_{d}$ for each land cover type within a grid cell (recall sub-tiling framework described above), which allows for a more direct comparison with observations (e.g., Paulot et al. (2018), Silva and Heald (2018)). The model land cover type that best matches the observational site is selected for the evaluations in Figures 1 and 2. We focus our model evaluation on the eight sites with multiple years of data with at least a couple of months of data collected in a given year (Figure 1). At these sites, monthly daily mean $\mathrm{v}_{d}$ shows strong interannual variability, similar to that identified by Clifton et al. (2017) for monthly daytime mean $\mathrm{v}_{d}$ at Harvard Forest. For most sites, simulated $\mathrm{v}_{d}$ is close to the multiyear mean observed $\mathrm{v}_{d}$ and mostly within the observed range of interannual variability (Figure 1). Two exceptions are the sites in Italy during nonsummer months - whereas AM3DD slightly overestimates $\mathrm{v}_{d}$ at Castelporziano, AM3DD slightly underestimates $\mathrm{v}_{d}$ at Ispra. The model also slightly overestimates summer $\mathrm{v}_{d}$ at Grignon and winter $\mathrm{v}_{d}$ at Blodgett Forest, suggesting that the model may struggle to capture $\mathrm{v}_{d}$ in Mediterranean-like ecosystems. Nonetheless, overall, we suggest that AM3DD captures observed $\mathrm{v}_{d}$ patterns on a climatological basis at long-term monitoring sites.

At the sites with shorter-term measurements, simulated monthly mean $\mathrm{v}_{d}$ tends to overestimate observed $\mathrm{v}_{d}$ (Figure 2a,b,c,d), except for Lincove, the orange orchard in the Central Valley of California, during nonspring months. In general, long-term ozone flux observations at these sites are necessary to understand the full extent of the apparent biases. We note that the short-term observations from Bondville, Kane, and Sand Flats were used in the development of the nonstomatal deposition parameterization from Zhang et al. $(2002,2003)$ from which we use some initial resistances. Agreement between simulated and observed $\mathrm{v}_{d}$ at these sites is lower relative to other sites, suggesting model performance does not follow implicit tuning. 

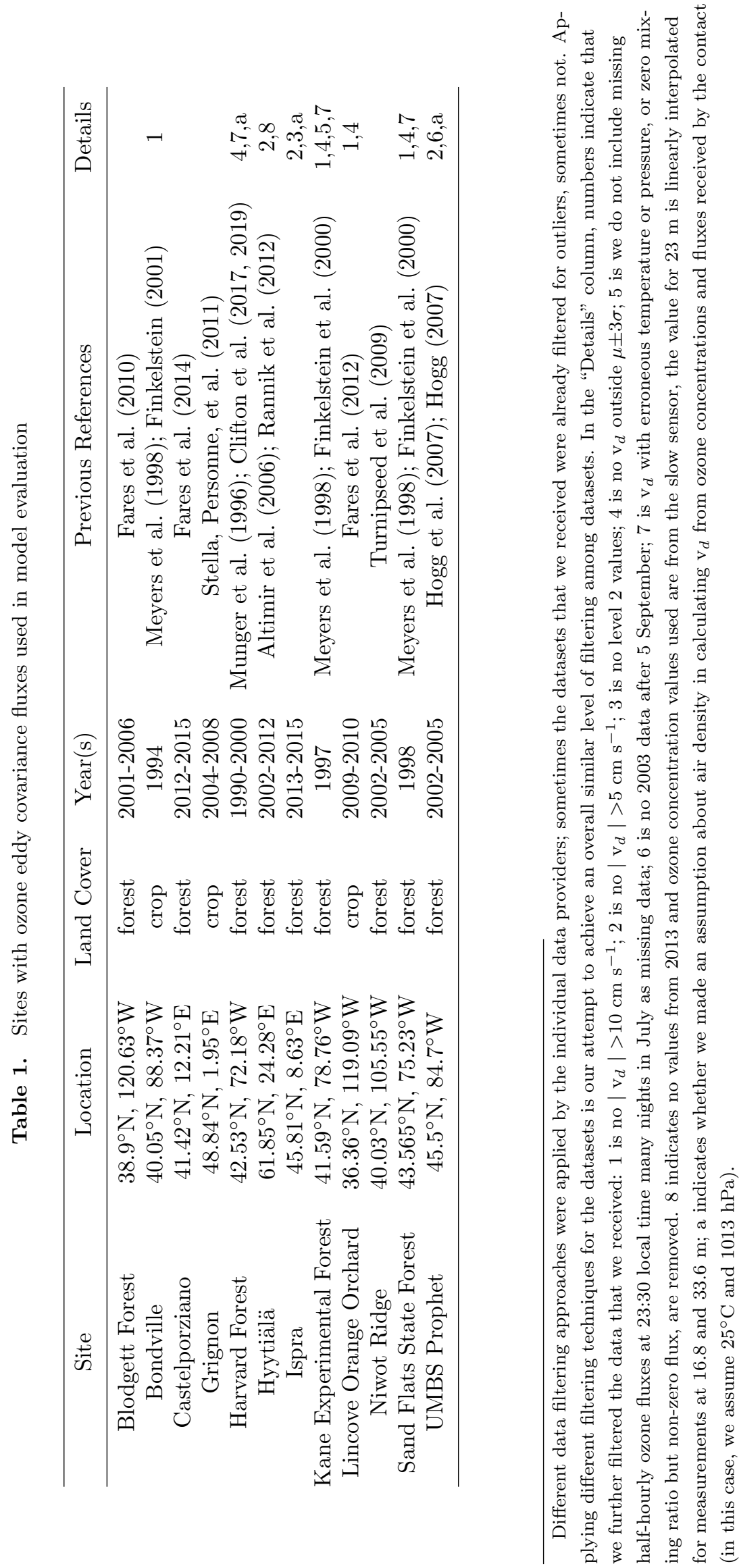

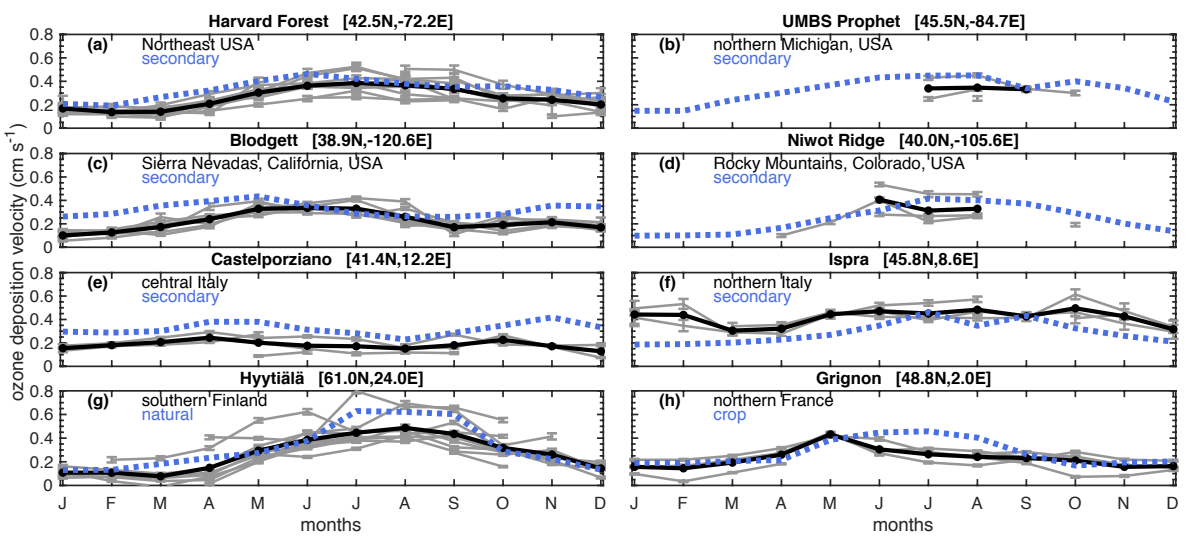

Figure 1. AM3DD evaluation of monthly daily (24-hour) mean ozone deposition velocity $\left(\mathrm{v}_{d}\right)$ at sites with ozone eddy covariance fluxes (see Table 1) for sites with multiple years of data with at least a couple of months of data collected in a given year. Grey indicates the observational monthly average for a given year; black shows the multiyear average when available. Blue dashed lines show simulated $\mathrm{v}_{d}$ for the land cover type that best characterizes the site (blue text). For the observations, we calculate the monthly average $\mathrm{v}_{d}$ using a bootstrapping technique (see Clifton et al. $(2017,2019)$ ). For a monthly average to be included, each hour of the day must have at least $25 \%$ data capture for the month. The error bars indicate the $95 \%$ confidence intervals.
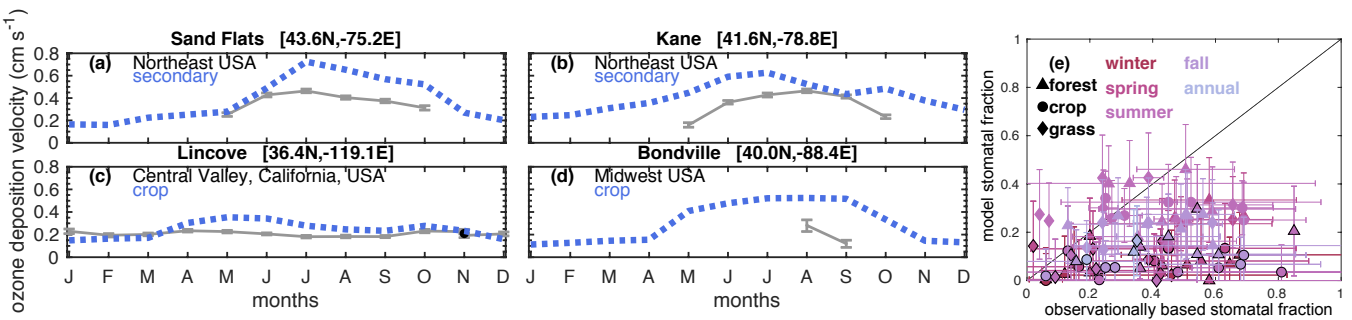

Figure 2. Model evaluation of variability in ozone dry deposition with short-term observational data. (a)-(d) As in Figure 1 but for sites with short-term data. (e) Comparison of simulated and observationally based daily mean (24-hour) stomatal fractions of ozone dry deposition. Error bars on the observationally based values indicate two standard deviations across estimates given for a particular site and season; error bars on simulated values indicate two standard deviations across daily values. Black outlines on symbols represent sites where modeled LAI is less than $1 \mathrm{~m}^{2} \mathrm{~m}^{-2}$, which may lead to underestimated stomatal fractions. Sites included are sites for which daily averages of the stomatal fraction were inferred from previous literature by Clifton et al. (2020). 
We compile estimates of the stomatal fraction of ozone dry deposition over physiologically active vegetated landscapes from previous literature to evaluate simulated partitioning between stomatal and nonstomatal deposition (Figure 2e). Estimates are based on ecosystem-scale ozone flux observations as well as micrometeorological observations used to infer stomatal uptake (e.g., through inversions of water vapor fluxes or empirical stomatal conductance models) and resistances to turbulent and diffusive transport. We include here estimates that represent daily (24-hour) averages. While both the model and observationally based estimates show co-dominant roles for stomatal and nonstomatal deposition, the simulated stomatal fraction is generally underestimated (only $37 \%$ of what it should be). However, sites with particularly low biases have very low simulated LAI (e.g., $83 \%$ site-specific seasonal mean modeled stomatal fractions of $<0.2$ have $<1 \mathrm{~m}^{2} \mathrm{~m}^{-2} \mathrm{LAI}$ ), suggesting that the cause of the bias may be due to the model's inability to capture the amount of vegetation at these locations (to the extent that LAI is reported for the observational sites, most have higher LAI than this). Most sites lack the coincident measurements of LAI and stomatal fraction, which we need to directly evaluate the model's strength at capturing stomatal fractions where LAI is simulated accurately. Nonetheless, for all model grid cells with summer mean LAI $>2 \mathrm{~m}^{2} \mathrm{~m}^{-2}$ between $35-50^{\circ} \mathrm{N}$, the simulated summer stomatal fraction of ozone dry deposition is 0.4 , matching the observationally based stomatal fraction (0.39). We therefore suggest that the model reasonably captures stomatal versus nonstomatal partitioning where substantial vegetation is simulated. In general, excessively low or high model LAI may imply a model overemphasis or underemphasis, respectively, of nonstomatal deposition.

\section{Impact of dynamic ozone dry deposition scheme on present-day sur- face ozone}

\subsection{Winter}

Winter surface ozone decreases by $10 \mathrm{ppb}$ on average across northern mid-latitudes (40-55 ${ }^{\circ} \mathrm{N}$; land only) in response to higher (but still low) winter $\mathrm{v}_{d}$ in AM3DD versus AM3DD-staticO3DD (Figure 3a,c). For example, regional mean decreases for the regions outlined on Figure 3a (hereafter, highlighted regions) range from 3 to $10 \mathrm{ppb}$, except over central Asia where there are increases of $2 \mathrm{ppb}$. Winter $\mathrm{v}_{d}$ is 0.11 to $0.15 \mathrm{~cm} \mathrm{~s}^{-1}$ in the monthly $\mathrm{v}_{d}$ climatology from GEOS-Chem for these regions, but 0.10 to $0.29 \mathrm{~cm} \mathrm{~s}^{-1}$ as simulated by AM3DD.

Simulated winter surface ozone in AM3DD better matches most ground-based observations across the northern hemisphere (Figure 4a,c,e), suggesting that ozone dry deposition may be key for representing winter surface ozone accurately. For the model evaluation of surface ozone, we use 2008-2015 average daily mean mixing ratios from individual stations compiled for the Tropospheric Ozone Assessment Report (TOAR) (Schultz et al., 2017; Schultz et al., 2017). Over North America, Europe, and parts of Asia, the bias (simulated-observed) improvement is mostly within 1-15 ppb, but there are improvements of greater than $15 \mathrm{ppb}$ at higher latitudes (e.g., parts of Canada). At a couple of the most northern sites in Alaska and Scandinavia, surface ozone becomes too low in AM3DD. Over central Asia, the bias changes sign, but is small.

Reductions in winter surface ozone at any location may stem from local, upwind, and remote increases in ozone dry deposition. The winter ozone bias decreases by $5-12$ $\mathrm{ppb}$ in the lower troposphere in AM3DD relative to AM3DD-staticO3DD across northern mid-latitudes and boreal regions $\left(40-65^{\circ} \mathrm{N}\right.$; land only) and remote locations where ozone sondes are regularly launched (Tilmes et al., 2012) (Figure 5) suggesting that ozone dry deposition influences baseline ozone, defined as ozone not recently influenced by local precursor emissions (HTAP, 2010). 

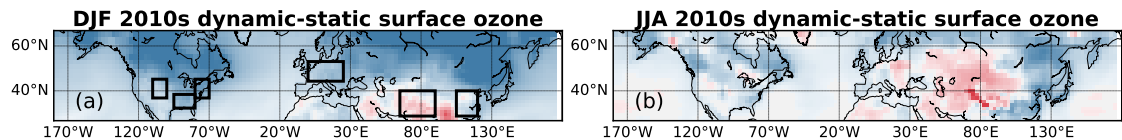

DJF 2010s dynamic-static $v_{d}$

JJA 2010s dynamic-static $\mathbf{v}_{d}$
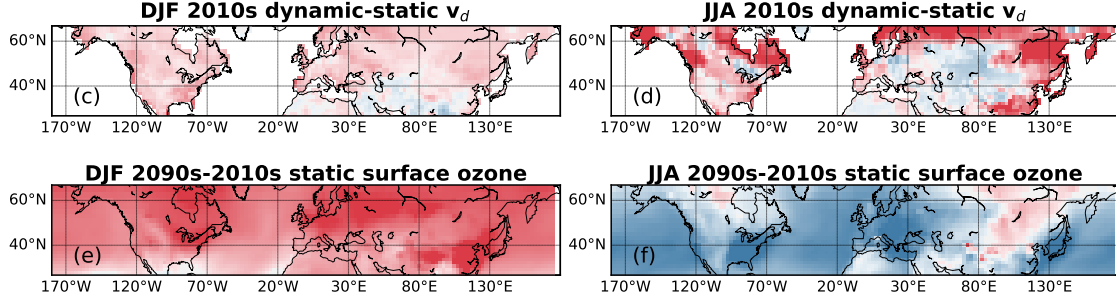

JJA 2090s-2010s static surface ozone

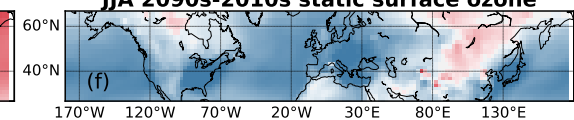

DJF 2090s-2010s dynamic surface ozone
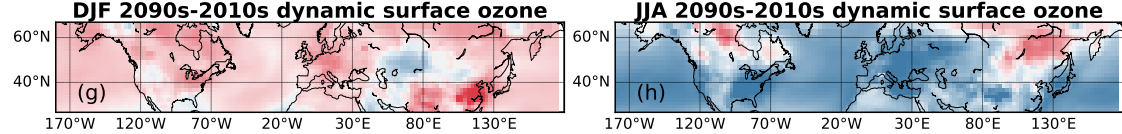

DJF 2090s-2010s dynamic $v_{d}$

JJA 2090s-2010s dynamic $v_{d}$
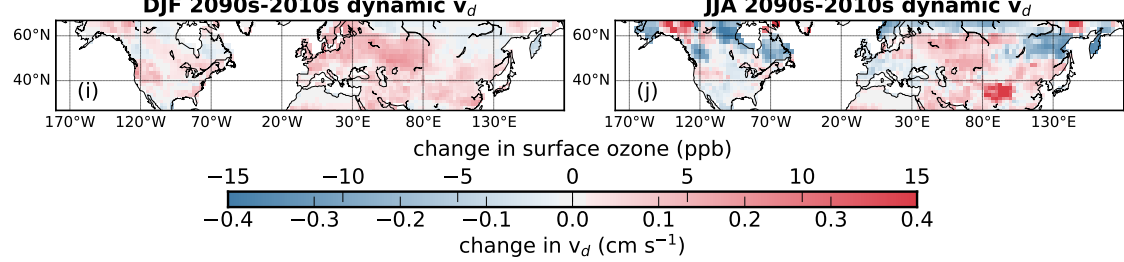

Figure 3. Winter (December-February, or DJF) and summer (June-August, or JJA) differences between AM3DD (dynamic) and AM3DD-staticO3DD (static) for surface ozone mixing ratios and ozone deposition velocity $\left(\mathrm{v}_{d}\right)$ at the 2010s, and differences between the 2090s and 2010s for $\mathrm{v}_{d}$ and surface ozone in AM3DD. We also show surface ozone differences between the 2090s and 2010s in AM3DD-staticO3DD. Black boxes on (a) represent regional definitions used in the paper and in subsequent figures. 
Winter $\mathrm{v}_{d}$ is zero at northern latitudes in AM3DD-staticO3DD where there is snow, defined in GEOS-Chem as albedo $>0.4$. Winter $\mathrm{v}_{d}$ is only lower in AM3DD versus AM3DDstaticO3DD over parts of Asia (Figure 3c). Differences in $\mathrm{v}_{d}$ in these regions likely stem from slightly higher LAI in the satellite-based climatology used in GEOS-Chem (Figure S1). At other mid-latitudes, $\mathrm{v}_{d}$ in AM3DD is higher than AM3DD-staticO3DD (e.g., by 0.02 to $0.14 \mathrm{~cm} \mathrm{~s}^{-1}$ ) and is almost completely dominated by ozone dry deposition to the ground (Figure 6a,c,e,g). Winter $\mathrm{v}_{d}$ in boreal regions with coniferous forests is dominated by uptake to cuticles (Figure 6a,c,e,g). While the comparison between LAI simulated by the model and LAI in the satellite-based climatology used in GEOS-Chem suggests near-zero LAI in boreal forests during winter and thus an overestimate of LAI in AM3DD, satellite-based estimates of LAI over boreal regions are particularly uncertain due to snow contamination and low solar zenith angle (Fang et al., 2013, 2019).

Our parameterization addresses observational evidence that (1) ozone dry deposition to snow-covered surfaces is low but nonzero (Helmig et al., 2007), (2) winter $\mathrm{v}_{d}$ is lower over snow-covered versus bare surfaces in temperate regions (Padro et al., 1992; Stocker et al., 1995; Helmig et al., 2007; Matichuk et al., 2017), and (3) ozone dry deposition to snow-covered forests is relatively high compared to other snow-covered surfaces (Z. Wu et al., 2016; Neirynck \& Verstraeten, 2018). While there is uncertainty in the initial resistances and other parameters employed here, as well as the exact processes controlling winter ozone dry deposition, our results suggest that considering this evidence and a more dynamic representation of snow cover may be important for capturing tropospheric ozone abundances accurately.

\subsection{Summer}

During June-August, surface ozone decreases on average by 5 ppb in AM3DD relative to AM3DD-staticO3DD over boreal latitudes where there is higher $\mathrm{v}_{d}$ in AM3DD (Figure $3 \mathrm{~b}, \mathrm{~d}$ ). Higher $\mathrm{v}_{d}$ over boreal latitudes is due to high stomatal and cuticular deposition to boreal coniferous forests (Figure $6 \mathrm{i}, \mathrm{k}, \mathrm{m}$ ). The summer surface ozone bias reduces by 1-10 ppb at all boreal monitoring sites except one (Figure 4b,d,f). However, LAI over much of the boreal forested region is higher than a satellite-based climatology (Figure S2), suggesting that ozone dry deposition may be too high over boreal forests and thus the substantial decrease in boreal surface ozone overestimated.

Over mid-latitudes, the sign of the change in summer surface ozone with dynamic ozone dry deposition varies (Figure 3b). Dynamic ozone dry deposition decreases the summer mean surface ozone bias over North America and Europe by 2-7 ppb, with the exceptions of eastern Europe and parts of the Great Lakes region of the US and western US where dynamic ozone dry deposition exacerbates the bias by 1-5 ppb (Figure 4f). Dynamic ozone dry deposition decreases the summer mean ozone bias over east Asia by up to $10 \mathrm{ppb}$, but worsens the bias at the limited monitoring sites in other parts of Asia. Model LAI overestimates in south China may suggest a $\mathrm{v}_{d}$ overestimate there, but ozone flux measurements are needed to confirm this. In general, the ozone bias is worse in regions where simulated LAI is lower than the satellite-based estimate (Figure S2), suggesting that $\mathrm{v}_{d}$ is underestimated because there is not enough vegetation. Due to the short summer surface ozone lifetime (e.g. a few days over continental northern mid-latitude regions), surface ozone differences between AM3DD and AM3DD-staticO3DD tend to mirror $\mathrm{v}_{d}$ differences (Figure $3 \mathrm{~b}, \mathrm{~d}$ ).

Summer mean decreases up to $7 \mathrm{ppb}$ in surface ozone occur over the southeast (SE) US. Such decreases may at least in part be due to wet cuticular deposition in AM3DD (Figure 6k), which is not simulated by the Wesely scheme in GEOS-Chem. The lack of wet cuticular deposition in most deposition schemes may thus contribute to the positive bias in modeled SE U.S. surface ozone (Fiore et al., 2009; Travis et al., 2016). Travis and 
DJF 2010s dynamic
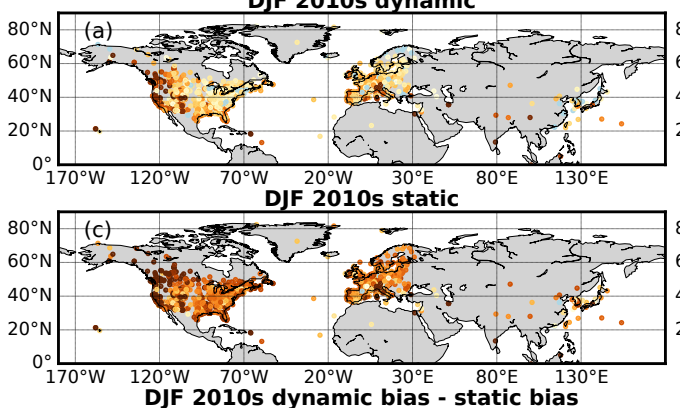
DJF 2010s dynamic bias - static bias
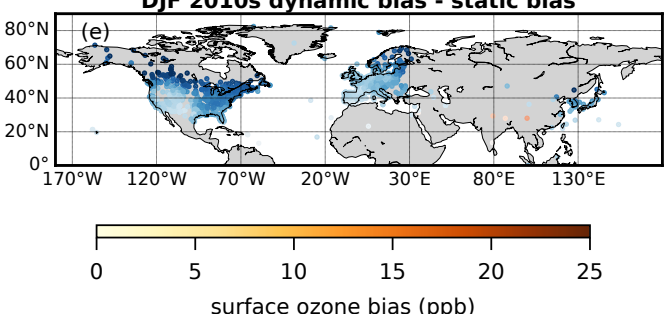

JJA 2010s dynamic
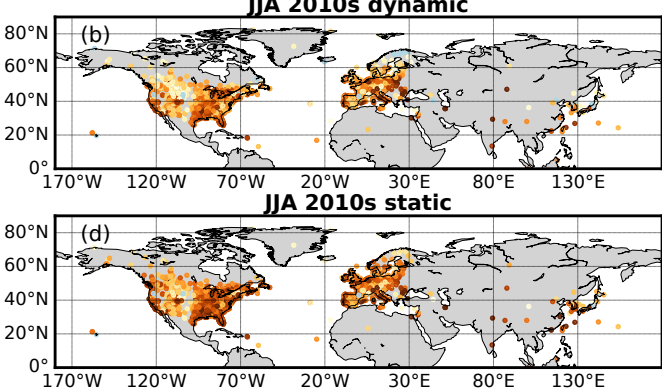

JA 2010s dynamic bias - static bias
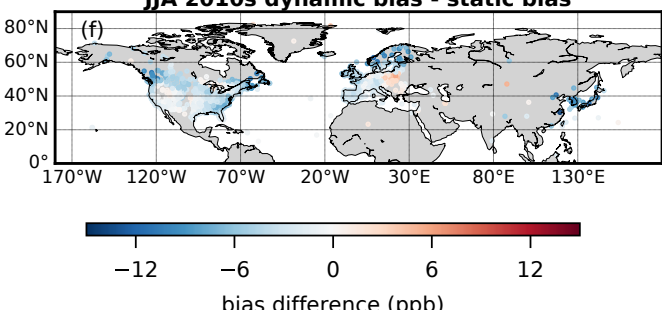

Figure 4. Winter (December-February, or DJF) and summer (June-August, or JJA) model evaluation using 2008-2015 mean surface ozone mixing ratios from individual stations compiled and calculated for the Tropospheric Ozone Assessment Report (TOAR) (Schultz et al., 2017; Schultz et al., 2017). In (a)-(d), we show the surface ozone bias (simulated minus observed) at each site for AM3DD (dynamic) and AM3DD-staticO3DD (static). Negative biases are shown in light blue. In (e)-(f), we show the difference in the biases. Negative values indicate improvement. If the bias is negative under AM3DD-staticO3DD then the site is not shown on (e)-(f) (the few removed sites are shown in light blue on panels (c)-(d)). We remove sites with less than $50 \%$ hourly data coverage (averaged over all winter or summer days in 2008 to 2015) and less than $50 \%$ of yearly coverage. We also discard sites characterized as traffic, industry, urban, and suburban by individual monitoring networks in order to lessen the influence of polluted urban air on our coarse-scale model evaluation, with the caveat that most sites are not classified. 

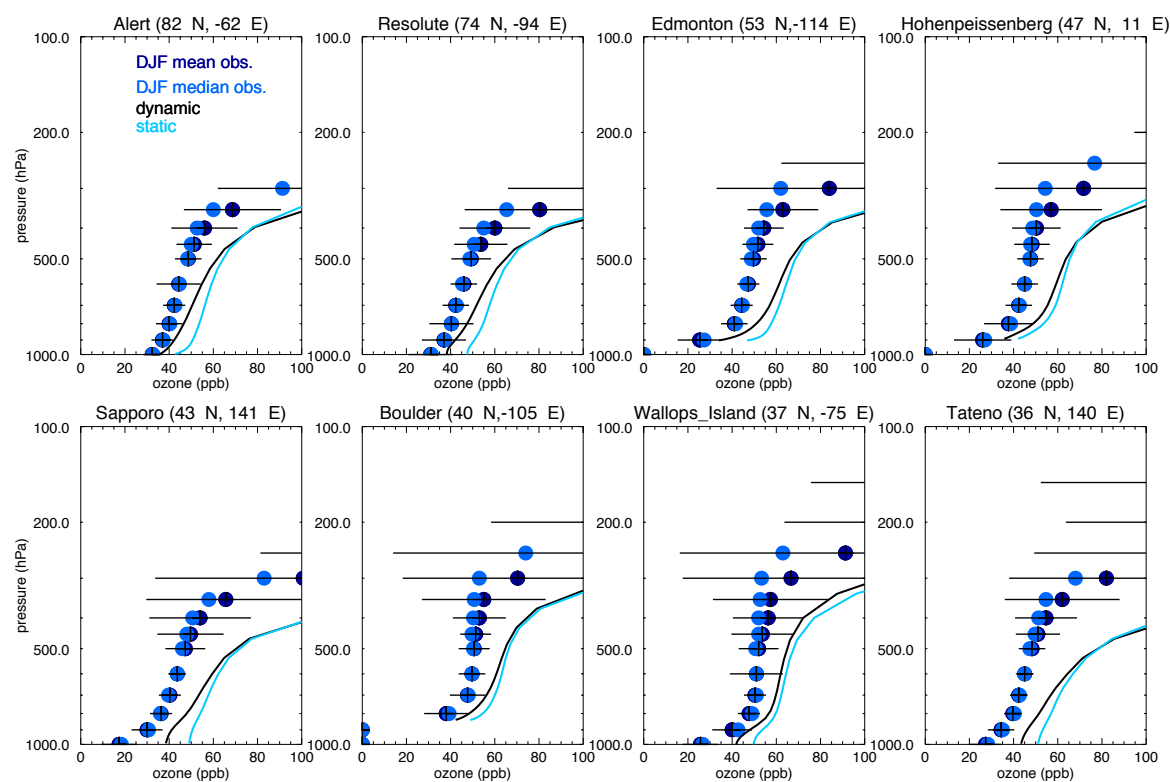

Figure 5. Winter (December-February, or DJF) model evaluation using 1995-2009 ozone vertical profiles from ozone sonde observations at individual stations north of $35^{\circ} \mathrm{N}$ from Tilmes et al. (2012) for AM3DD (dynamic) and AM3DD-staticO3DD (static).

Jacob (2019) also suggest the absence of this process prevents GEOS-Chem from capturing low SE U.S. surface ozone on rainy days.

Besides summer mean differences in surface ozone between AM3DD and AM3DDstaticO3DD, there are also differences in daily probability distributions (Figure 7a-f). For the SE US, the distribution decreases and there are larger changes for wet days ( $>6$ $\mathrm{mm}$ day $^{-1}$ precipitation as defined in Travis and Jacob (2019)) versus all days in AM3DD relative to AM3DD-staticO3DD, suggesting that high $\mathrm{v}_{d}$ on rainy days drives regional surface ozone decreases with dynamic ozone dry deposition. For the Northeast (NE) US and the InterMountain West (IMW) US, the mode of the distribution decreases, and the distribution shifts towards lower values. For central Asia, the mode of the distribution also decreases but the distribution shifts towards higher values. For central Europe, the distribution widens, with higher and lower surface ozone extremes.

Daily variability in $\mathrm{v}_{d}$ in AM3DD may drive the changes in the distribution of surface ozone across days. However, there is some evidence that mean changes in $\mathrm{v}_{d}$ may contribute to changes in relative variability in surface ozone. For example, reducing $\mathrm{v}_{d}$ by $35 \%$ over drought-stricken regions of the eastern US in 1988 with the version of AM3 employing the monthly $\mathrm{v}_{d}$ climatology shifts the ozone distribution towards higher values, but also slightly decreases the mode of the distribution (M. Lin et al., 2017), implying a nonlinear ozone response to a mean shift in $\mathrm{v}_{d}$. Disentangling contributions to the changes in the surface ozone distribution from daily-varying $\mathrm{v}_{d}$ versus a nonlinear ozone sensitivity to $\mathrm{v}_{d}$ is not possible with our simulations. Nonetheless, strong correlations between $\mathrm{v}_{d}$ and surface ozone on daily timescales (Figure $7 \mathrm{~g}$ ) suggest that dayto-day variability in ozone dry deposition plays an important role in shaping the surface ozone distribution across days.

Kavassalis and Murphy (2017) hypothesize variability in stomatal ozone dry deposition influences daily variability in ozone pollution on the basis of the strong correlation between observed surface ozone concentrations and vapor pressure deficit and a 


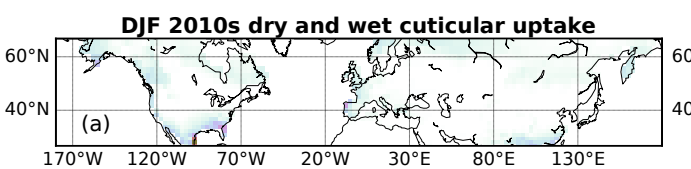

DJF 2090s-2010s dry and wet cuticular uptake

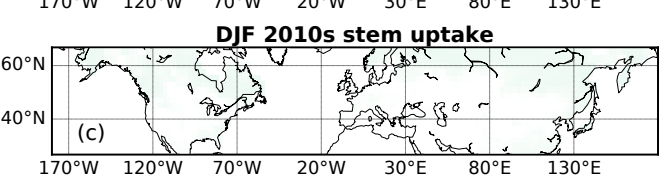

DJF 2010s snow uptake to cuticles and ground

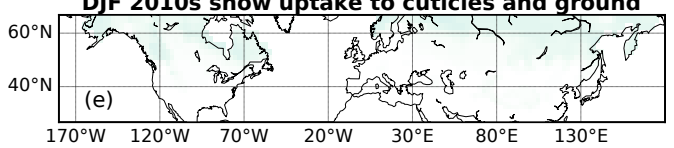

DJF 2010s dry ground uptake

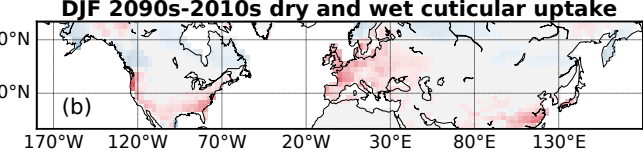

DJF 2090s-2010s stem uptake
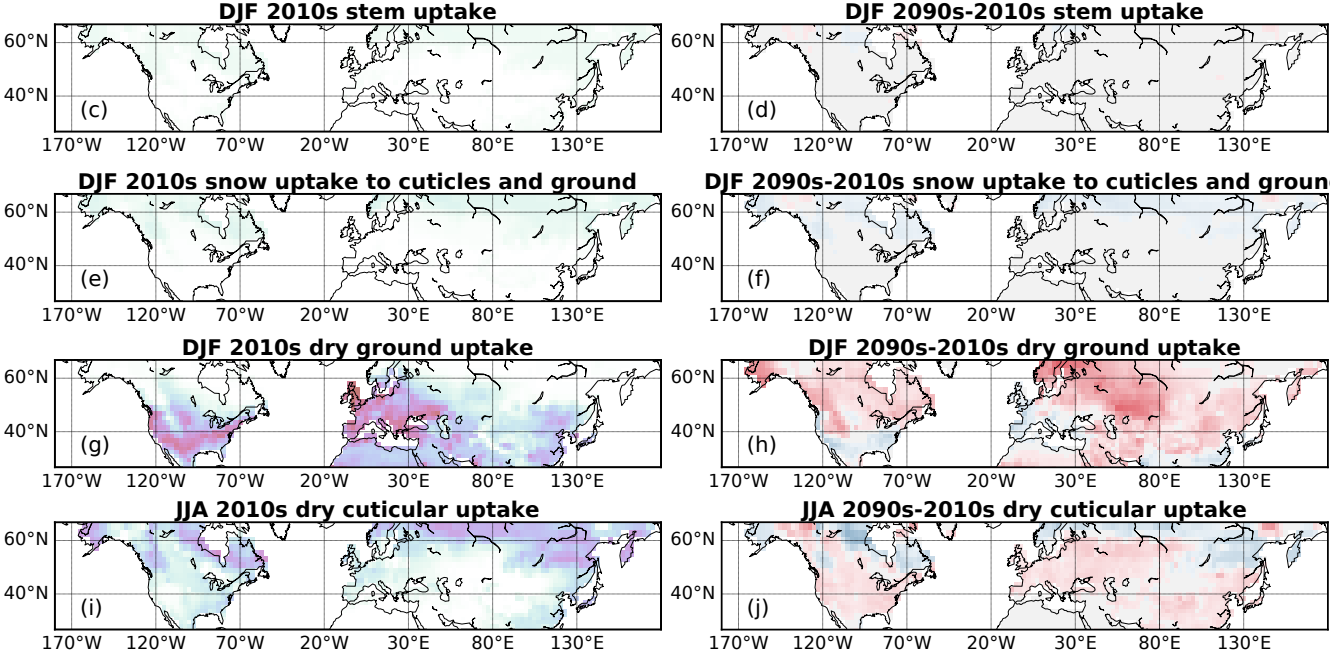

DJF 2090s-2010s snow uptake to cuticles and ground

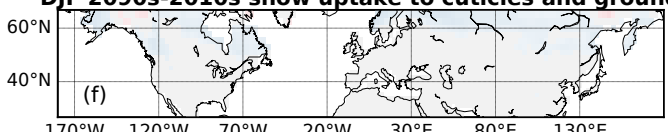

DJF 2090s-2010s dry ground uptake

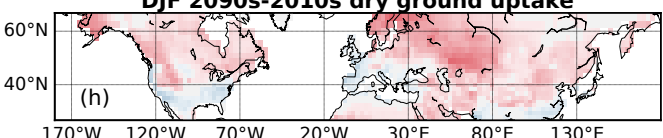

JJA 2090s-2010s dry cuticular uptake

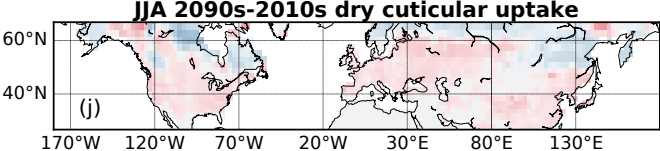

JJA 2010s wet cuticular uptake

JJA 2090s-2010s wet cuticular uptake
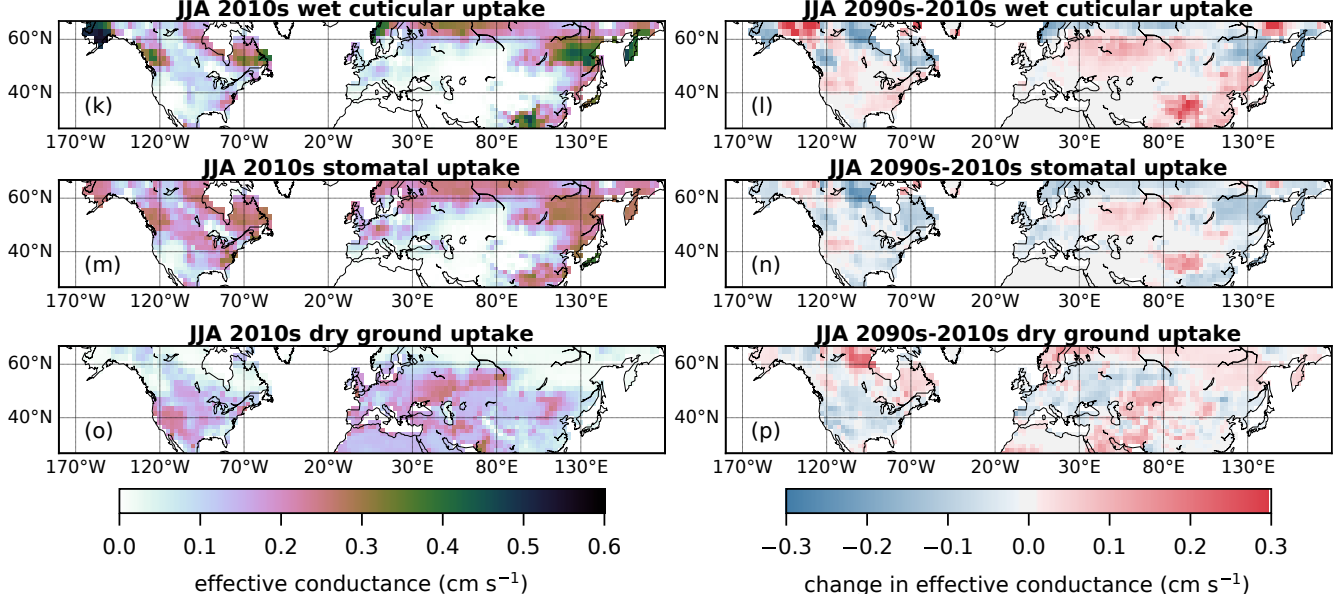

Figure 6. Winter (December-January, or DJF) and summer (June-August, or JJA) effective conductances at the 2010s, and differences between the 2090s and 2010s under AM3DD. For a given season, we only show deposition pathways that substantially contribute to ozone deposition velocity $\left(\mathrm{v}_{d}\right)$; the effective conductances shown sum to $\mathrm{v}_{d}$. The change in the effective conductances sum to the net change in $\mathrm{v}_{d}$ from the 2010s to 2090s shown in Figure 3. For all panels, grid cells with less than $50 \%$ land are not included. 
strong dependence of stomatal conductance on dryness. In AM3DD, nonstomatal deposition is an important fraction of the total ozone dry deposition (Figure 6i,k,m,o) and a key driver of daily variability in summer $\mathrm{v}_{d}$ (Figure 7i-l), suggesting that dynamic nonstomatal deposition also influences daily variability in surface ozone. In particular, wet cuticular and ground deposition vary, reflecting the influence of soil and leaf wetness, respectively, as well as in-canopy turbulence for the latter, and dominate the variability in $\mathrm{v}_{d}$ in many regions (Figure $7 \mathrm{i}-\mathrm{l}$ ).

The correlation between wet cuticular and stomatal deposition (Figure $7 \mathrm{~h}$ ) and the substantial magnitude and variability that each of these terms provides summer $\mathrm{v}_{d}$ (Figures $6 \mathrm{i}, \mathrm{k}, \mathrm{m}, \mathrm{o}$ and 7i-l) imply that an unambiguous attribution of increases in ozone pollution during drought to reductions in stomatal deposition may be challenging. M. Lin et al. (2019) use a similar version of the GFDL model to conclude that variations in stomatal deposition drive variations in ozone pollution with drought. However, M. Lin et al. (2019) do not consider how variations in cuticular uptake with precipitation influence variability in $\mathrm{v}_{d}$ and thus their conclusion may need to be re-visited.

Most studies examining observed $\mathrm{v}_{d}$ after rain and dew report increases (Clifton et al., 2020). While laboratory and field chamber evidence support increases in cuticular deposition to wet leaves (Fuentes \& Gillespie, 1992; Pleijel et al., 1995; Sun et al., 2016; Potier et al., 2017), whether increases in ecosystem-scale $\mathrm{v}_{d}$ after rain and dew are due to wet cuticular deposition is uncertain. For example, changes in other processes (e.g., stomatal conductance, in-canopy chemistry) may contribute to observed increases (Altimir et al., 2006; Turnipseed et al., 2009; Clifton et al., 2019). Canopy interception of water is also an uncertain component of land models (Bonan \& Levis, 2006; De Kauwe et al., 2013; Lian et al., 2018; Fan et al., 2019) and contributes to uncertainty in simulated wet cuticular deposition. The amount of canopy-intercepted precipitation in LM3 is lower than observation-based estimates (Milly et al., 2014) and additional uncertainty includes the duration and fraction of wet leaves.

In general, AM3DD may not capture the partitioning of $\mathrm{v}_{d}$ to individual pathways accurately due to process and parameter uncertainty (e.g., $\mathrm{m}, \mathrm{d}_{0}$, all initial resistances). Indeed, recent work identifies factor of 2-3 differences in simulated $\mathrm{v}_{d}$ due to process representation and parameter choice (Z. Wu et al., 2018; Wong et al., 2019). Given that AM3DD seems to capture the magnitude of $\mathrm{v}_{d}$, model LAI under- or overestimates (Figure S2) may imply a nonstomatal deposition over- or underemphasis, respectively. Comparisons with other models that prognostically simulate the components of ozone dry deposition (i.e., LAI, soil moisture) will be useful for assessing confidence in the contribution of different processes to ozone dry deposition as represented in current models.

\section{$521^{\text {st }}$-century changes in surface ozone from dynamic ozone dry de- position}

\subsection{Winter northern mid-latitudes}

Over northern mid-latitudes, winter surface ozone increases with the $21^{s t}$-century reductions in anthropogenic nitrogen oxide $\left(\mathrm{NO}_{x}\right)$ emissions (i.e., 2010-to-2090 decreases of $57-69 \%$ for the highlighted regions) and doubling of global methane under RCP8.5 (i.e., $105 \%$ increase from 2010 to 2090) (Gao et al., 2013; Clifton et al., 2014). More specifically, reductions in regional $\mathrm{NO}_{x}$ emissions under RCP8.5 over polluted mid-latitudes lead to a reversal of surface ozone seasonality from a summer to a winter peak and the global methane doubling amplifies hemispheric-scale ozone (Clifton et al., 2014).

We find here that increasing winter $\mathrm{v}_{d}$ during the $21^{\text {st }}$ century tempers the rise in winter surface ozone over mid-latitudes in AM3DD relative to AM3DD-staticO3DD (Figure $3 \mathrm{e}, \mathrm{g}, \mathrm{i}$ ). For example, $21^{\text {st }}$-century increases in winter surface ozone are lower on average by 4-8 ppb in AM3DD relative to AM3DD-staticO3DD for highlighted regions. Over 
some parts of Asia, changes in local and remote ozone dry deposition tip the balance towards $21^{\text {st }}$-century decreases in winter ozone.

Higher winter $\mathrm{v}_{d}$ by the 2090s at mid-latitudes mainly reflects higher ground deposition and higher dry and wet cuticular deposition (Figure 6b,d,f,h). There is higher ground deposition due to less snow. Andersson and Engardt (2010) also find that decreasing snow over Europe with climate warming is an important driver of regional $\mathrm{v}_{d}$ and ozone pollution for their April-October analysis. Increases in winter $\mathrm{v}_{d}$ from higher cuticular deposition are likely associated with warmer winters and higher LAI (Figure S3) from the long-term effects of carbon dioxide fertilization (i.e., plants accumulate more biomass under high carbon dioxide).

\subsection{Summer northern mid-latitudes}

Large summer decreases in surface ozone from the 2010s to the 2090s over polluted northern mid-latitudes occur as regional anthropogenic $\mathrm{NO}_{x}$ emissions decline under RCP8.5 (Gao et al., 2013; Clifton et al., 2014; Rieder et al., 2018). Similar to AM3DD-staticO3DD, summer surface ozone decreases over most mid-latitudes in AM3DD (Figure 3f,h). For highlighted regions, the $21^{\text {st }}$-century decrease in surface ozone is -7 to $-17 \mathrm{ppb}$ in AM3DD versus -2 to $-19 \mathrm{ppb}$ in AM3DD-staticO3DD; the decrease weakens by about $1 \mathrm{ppb}$ in AM3DD except over central and east Asia where the decreases are the same or become stronger by $4 \mathrm{ppb}$, respectively.

Over several mid-latitude regions, opposing changes in individual deposition pathways from the 2010 s to the 2090 s offset each other, leading to little net $21^{\text {st }}$-century change in $\mathrm{v}_{d}$. For example, summer dry cuticular deposition increases nearly everywhere from the long-term effects of carbon dioxide fertilization promoting leaf biomass accumulation (Figure 6j). Wet cuticular deposition increases or does not change at most mid-latitudes (Figure 61); regions with increases in wet cuticular deposition are regions with increases in rainfall and regions with no change are regions with decreases in rainfall (Figure S4b). Ground deposition decreases or does not change in most mid-latitude regions, except western Asia (Figure 6h). Changes in ground deposition mostly reflect higher LAI, which raises the resistance to in-canopy turbulence and decreases ground uptake, rather than changes in soil wetness, which are mostly decreases and would lead to increases in ground uptake (Figures S4a,d). Summer stomatal deposition either does not change or decreases over most mid-latitude regions (Figure 6n) despite widespread increases in LAI, likely due to increased dryness and the short-term (i.e., instantaneous) effects of carbon dioxide that decrease stomatal conductance (Figure S4c,d). Exceptions include western Asia and the western US where there is vegetation at end of the century but not at the beginning (compare Figures S2b and S4a).

\subsection{Summer and winter boreal regions}

With the prescription of land use change under RCP8.5 and the expansion of deciduous forests into boreal latitudes simulated by the vegetation dynamics in LM3, there are $21^{\text {st }}$-century decreases in winter and summer cuticular deposition (Figures 6b,f,j,l) over boreal regions with conifers at the 2010s. Such decreases likely occur because the model generally simulates lower LAI for deciduous forests, pastures, and crops relative to coniferous forests (not shown). There are $21^{s t}$-century decreases in summer stomatal deposition over these boreal regions (Figure $6 \mathrm{n}$ ), likely following decreases in LAI but also the short-term impact of high carbon dioxide. In the regions north of $50^{\circ} \mathrm{N}$ with deciduous forests throughout the $21^{\text {st }}$ century, increases in winter and summer $\mathrm{v}_{d}$ follow less snow (winter only) and higher LAI from carbon dioxide fertilization.

Our findings contrast with S. Wu et al. (2012) who find widespread increases in boreal summer $\mathrm{v}_{d}$ between 2000 and 2100. Differences in $\mathrm{v}_{d}$ between AM3DD and their 

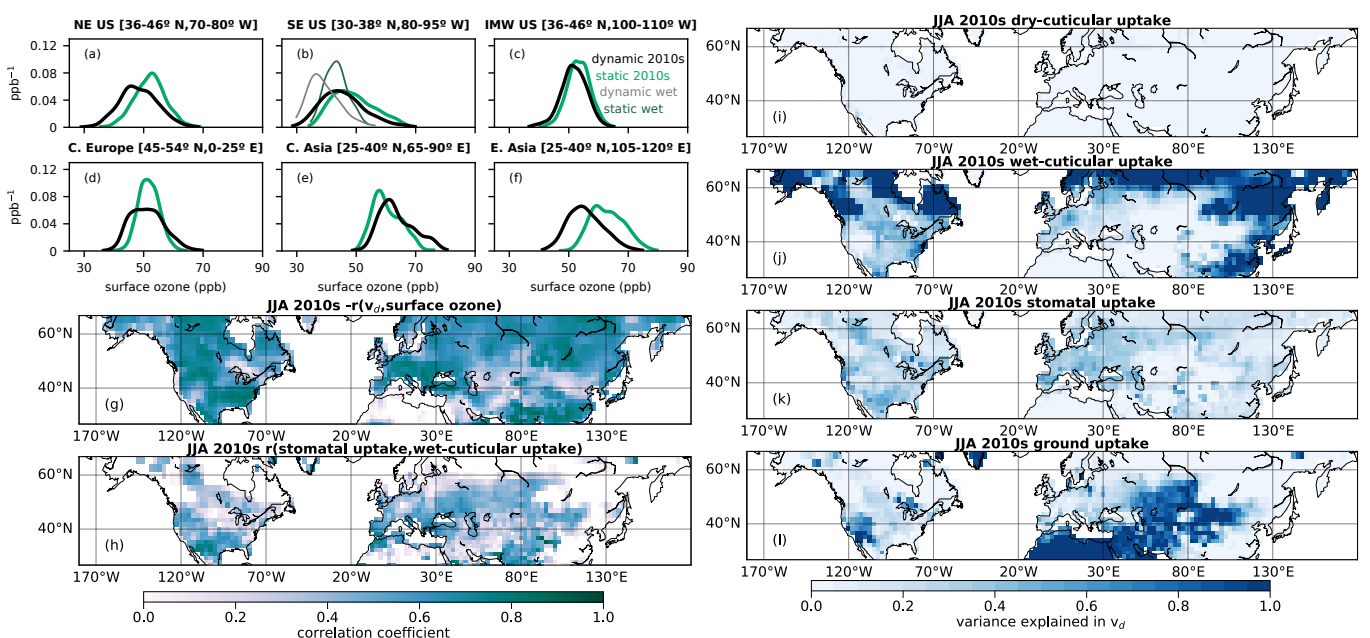

Figure 7. Daily variability in surface ozone and ozone dry deposition. (a)-(f) Summer (JuneAugust) probability density functions of daily regional average surface ozone mixing ratios for the 2010s in several northern mid-latitude regions for AM3DD (dynamic) and AM3DDstaticO3DD (static) estimated with a Gaussian kernel density. The regions are indicated with black lines on Figure 3a. For the southeast US, we also include probability density functions for wet days only (defined as $6 \mathrm{~mm} \mathrm{day}^{-1}$ on a regional average basis). (g) Correlation coefficient between day-to-day variability in summer surface ozone and ozone deposition velocity $\left(\mathrm{v}_{d}\right)$ in AM3DD. (h) Correlation coefficient between day-to-day variability in summer effective stomatal and wet-cuticular conductances in AM3DD. For $(\mathrm{g})-(\mathrm{h})$, white space on land denotes correlations outside the color bar. In (g), all correlations shown are negative but displayed as positive. (i)-(l) Variance explained in summer daily $\mathrm{v}_{d}$ by individual deposition pathways for AM3DD. We use the variance formula for variables that are not independent from each other $\left(\operatorname{Var}\left(\sum_{i=1}^{n} X_{i}\right)=\sum_{i=1}^{n} \operatorname{Var}\left(X_{i}\right)+2 \sum_{1 \leq i \leq j<n} \operatorname{Cov}\left(X_{i}, X_{j}\right)\right)$ because each effective conductance is the fraction of deposition through a certain pathway multiplied by $\mathrm{v}_{d}$. For all panels, grid cells with less than $50 \%$ land are not included. 
model (the dynamic vegetation model described in Sitch et al. (2003)) result from different prognostically determined LAI (i.e., their model shows $21^{\text {st }}$-century LAI increases over boreal regions), prescriptions of land use change, and stomatal conductance parameterizations. S. Wu et al. (2012) use a Jarvis (1976) stomatal conductance model rather than a coupled net photosynthesis-stomatal conductance model as used here. While their stomatal conductance parameterization considers the long-term effect of carbon dioxide on LAI, it does not consider the short-term effect on stomatal conductance.

In general, $21^{\text {st }}$-century carbon dioxide fertilization is uncertain (Wieder et al., 2015; N. G. Smith et al., 2016; W. K. Smith et al., 2016; Yuan et al., 2019; Terrer et al., 2016; Sulman et al., 2019; Humphrey et al., 2018; Green et al., 2019; Friedlingstein et al., 2006; Gerber et al., 2010). For example, changes in other processes may offset or exacerbate the impacts of high carbon dioxide on stomatal conductance and LAI (e.g., nutrient limitation). A better understanding of carbon dioxide fertilization will not only lead to more accurate projections of stomatal deposition, but also nonstomatal deposition.

\section{Conclusion}

Limited representation of ozone dry deposition in atmospheric chemistry models hampers understanding of ozone pollution because simulated surface ozone is sensitive to $\mathrm{v}_{d}$ (J.-T. Lin et al., 2008; Walker, 2014; Hogrefe et al., 2018). Here we use a new version of the NOAA GFDL global chemistry-climate model, AM3DD, that leverages the dynamics of the underlying land model to simulate dry deposition of some aerosols and reactive trace gases, including ozone. Particularly novel features of the dynamic ozone dry deposition scheme are dependencies of nonstomatal deposition processes on soil moisture, canopy humidity, and canopy interception of water and snow and stomatal deposition on photosynthesis, vapor pressure deficit, and soil moisture. We use this new tool to investigate the influence of ozone dry deposition on surface ozone at northern midlatitudes at the beginning and end of the $21^{\text {st }}$ century. While stomatal deposition has long been recognized as an important driver of ozone dry deposition, we show that the $\mathrm{v}_{d}$ spatial distribution, daily variability, and $21^{\text {st }}$-century changes also depend on nonstomatal deposition.

The new version of the GFDL model improves the simulation of winter ozone at surface monitoring sites and in the lower troposphere at remote sites relative to the version of the model driven with a $\mathrm{v}_{d}$ climatology. Higher simulated winter $\mathrm{v}_{d}$ in AM3DD reflects our use of interactive snow dynamics and recognizing non-negligible winter ozone dry deposition, as supported by observations. A major finding from our study is that winter ozone dry deposition influences baseline ozone, suggesting that remote ozone dry deposition is an important lever on a given region's ozone pollution. We also find that large-scale increases in winter $\mathrm{v}_{d}$ during the $21^{\text {st }}$ century under RCP8.5 limit the influence of rising global methane on surface ozone (e.g., Clifton et al. (2014)). For example, the change in winter surface ozone from the 2010s to 2090s with dynamic ozone dry deposition is 1 to $13 \mathrm{ppb}$ over the northern mid-latitude regions highlighted here versus 6 to $21 \mathrm{ppb}$ with the climatology.

The dynamic ozone dry deposition scheme generally leads to -4 to $+7 \mathrm{ppb}$ changes in mean summer surface ozone at the 2010s over northern mid-latitudes relative to the simulation forced with a $\mathrm{v}_{d}$ climatology. We find that daily variations in summer $\mathrm{v}_{d}$ with meteorology and biophysics, including from nonstomatal deposition processes, contribute to daily variations in ozone pollution. Evidence includes differences in daily ozone probability distributions between simulations with dynamic ozone dry deposition versus the climatology, daily correlations between surface ozone and $\mathrm{v}_{d}$ in the dynamic simulation, and the high fraction of variance explained by nonstomatal deposition in simulated daily variations in $\mathrm{v}_{d}$. Our new dry deposition configuration supports a role for ozone dry deposition on rainy days in the pervasive summer surface ozone bias over the southeast US. 
In general, simulated cuticular deposition varies similarly to stomatal deposition, suggesting unambiguous attribution of variations in $\mathrm{v}_{d}$ and ozone pollution to stomatal deposition may be challenging. Studies pinpointing the drivers of day-to-day variability in observed $\mathrm{v}_{d}$ will be useful for ensuring that regional-to-global models capture the response of summer ozone dry deposition to meteorological and biophysical variability accurately.

Mostly $21^{\text {st }}$-century changes in summer surface ozone at northern mid-latitudes under RCP 8.5 are similar with dynamic ozone dry deposition (around $1 \mathrm{ppb}$ difference). One exception is east Asia where increasing $\mathrm{v}_{d}$ leads to a $4 \mathrm{ppb}$ stronger decrease in summer surface ozone. In general, there are changes in summer ozone deposition pathways with changes in rainfall, dryness and carbon dioxide. However, changes in individual pathways tend to offset one another and thus there is not much impact on the change in summer surface ozone. The extent to which this offsetting occurs, however, depends fundamentally on assumptions inherent to the representation of different depositional processes in the model. Given the reliance of all ozone dry deposition parameterizations on myriad uncertain tuning parameters that determine the magnitude of the $21^{\text {st }}$-century changes in individual deposition processes, improved understanding of such processes is needed (e.g., Clifton et al. (2020)).

\section{Acknowledgments}

This study was supported by an NSF Graduate Research Fellowship (DGE 16-44869) to O.E.C., NOAA's Climate Program Office's Atmospheric Chemistry, Carbon Cycle, and Climate program grant NA14OAR4310133 to A.M.F., and an Advanced Study Program postdoctoral fellowship from the National Center for Atmospheric Research to O.E.C. Thus this material is based upon work supported by the National Center for Atmospheric Research, which is a major facility sponsored by the National Science Foundation under Cooperative Agreement No. 1852977. We gratefully acknowledge Vaishali Naik for sharing code for ozone sonde evaluation, Elena Shevliakova and Sergey Malyshev for insightful discussions of land model processes and parameterizations, Steven Bertman, Alina Drebin, and Jason Tallant for organizing and processing the data from UMBS Prophet, Andrew Turnipseed and the Niwot Ridge Ameriflux site for providing the data from Niwot Ridge, Donna Schwede for providing the data from Kane Experimental Forest, Sand Flats State Forest, and Bondville, Louisa Emmons for helpful comments on the manuscript, and the TOAR initiative (http://www.igacproject.org/activities/TOAR) for providing a global dataset of surface ozone observations. Harvard Forest observations were supported in part by the U.S. Department of Energy, Office of Science (BER), and NSF LongTerm Ecological Research. Grignon observations were supported by EU FP7 IP-NitroEurope and IP-ECLAIRE. Datasets used for all figures that are not already available online will be included in the Columbia Academic Commons (archival is ongoing so for now data is included as supplementary material). Datasets online in other locations are observationally based estimates of the stomatal fraction of ozone dry deposition (https://doi.org/10.5065/w2zcbt87), ozone eddy covariance fluxes from Harvard Forest (https://doi.org/10.6073/pasta/74fe96d1571db7f15bf6f1c Grignon and Castelporziano (https://www.europe-fluxdata.eu), Hyytiälä (https://avaa.tdata.fi/web/smart/smear Kane Experimental Forest and Sand Flats State Forest (https://doi.org/10.7916/d8-vkzxqb85), and UMBS Prophet (https://biostation.lsa.umich.edu/content/ozone-concentationsand-ozone-flux-2002-2005-umbs-prophet-tower), surface ozone observational data (https://doi.org/10.1594/PANG ozone sonde observational data (https://doi.org/10.5065/D6NS0S3M) and GEOS-Chem MODIS LAI data (http://geoschemdata.computecanada.ca/ExtData/CHEM INPUTS/MODIS LAI'201204/For 'O We thank three anonymous reviewers for their helpful reviews.

\section{References}

Aldaz, L. (1969). Flux measurements of atmospheric ozone over land water. Journal of Geophysical Research, 74. doi: 10.1029/JC074i028p06943

Altimir, N., Kolari, P., Tuovinen, J.-P., Vesala, T., Bäck, J., Suni, T., .. Hari, P. 
(2006). Foliage surface ozone deposition: a role for surface moisture? Biogeosciences, 3(2), 209-228. doi: 10.5194/bg-3-209-2006

Anav, A., Proietti, C., Menut, L., Carnicelli, S., De Marco, A., \& Paoletti, E. (2018). Sensitivity of stomatal conductance to soil moisture: Implications for tropospheric ozone. Atmospheric Chemistry and Physics, 18(8), 5747-5763. doi: $10.5194 /$ acp-18-5747-2018

Andersson, C., \& Engardt, M. (2010). European ozone in a future climate: Importance of changes in dry deposition and isoprene emissions. Journal of Geophysical Research: Atmospheres, 115(2), 1-13. doi: 10.1029/2008JD011690

Bonan, G. B. (1996). Land surface model (lsm version 1.0) for ecological, hydrological, and atmospheric studies: Technical description and users guide. technical note (Tech. Rep.). National Center for Atmospheric Research, Boulder, CO, United States. doi: 10.5065/D6DF6P5X

Bonan, G. B., \& Levis, S. (2006). Evaluating aspects of the community land and atmosphere models (clm3 and cam3) using a dynamic global vegetation model. Journal of Climate, 19(11), 2290-2301.

Burkhardt, J., \& Hunsche, M. (2013). "breath figures" on leaf surfaces - formation and effects of microscopic leaf wetness. Frontiers in Plant Science, 4(422), 1-9. doi: 10.3389/fpls.2013.00422

Businger, J. A., Wyngaard, J. C., Izumi, Y., \& Bradley, E. F. (1971). Flux-Profile Relationships in the Atmospheric Surface Layer. Journal of the Atmospheric Sciences, 28(2), 181-189.

Choudhury, B. J., \& Monteith, J. L. (1988). A four-layer model for the heat budget of homogeneous land surfaces. Quarterly Journal of the Royal Meteorological Society, $114(480), 373-398$.

Cieslik, S. (2009). Ozone fluxes over various plant ecosystems in italy: A review. Environmental Pollution, 157(5), 1487-1496. doi: 10.1016/j.envpol.2008.09.050

Clifton, O. E., Fiore, A. M., Correa, G., Horowitz, L. W., \& Naik, V. Twenty-first century reversal of the surface ozone seasonal cycle over the northeastern united states. Geophysical Research Letters, 41(20), 7343-7350. doi: 10.1002/2014GL061378

Clifton, O. E., Fiore, A. M., Massman, W. J., Baublitz, C. B., Coyle, M., Emberson, L., ... Tai, A. P. (2020). Dry deposition of ozone over land: Processes, measurement, and modeling. Reviews of Geophysics. doi: 10.1029/2019RG000670

Clifton, O. E., Fiore, A. M., Munger, J. W., Malyshev, S., Horowitz, L. W., Shevliakova, E., .. Griffin, K. L. (2017). Interannual variability in ozone removal by a temperate deciduous forest. Geophysical Research Letters, 44 (1), 542-552. doi: $10.1002 / 2016 \mathrm{gl} 070923$

Clifton, O. E., Fiore, A. M., Munger, J. W., \& Wehr, R. (2019). Spatiotemporal controls on observed daytime ozone deposition velocity over northeastern u.s. forests during summer. Journal of Geophysical Research: Atmospheres. doi: 10.1029/2018JD029073

Colbeck, I., \& Harrison, R. M. (1985). Dry deposition of ozone - some measurements of deposition velocity and of vertical profiles to 100-metres. Atmospheric Environment, 19, 1807-1818. doi: 10.1016/0004-6981(85)90007-1

Collatz, G. J., Ball, J. T., Grivet, C., \& Berry, J. A. (1991). Physiological and environmental regulation of stomatal conductance, photosynthesis and transpiration: a model that includes a laminar boundary layer. Agricultural and Forest Meteorology, 54(2), 107 - 136. doi: 10.1016/0168-1923(91)90002-8

Collatz, G. J., Ribas-Carbo, M., \& Berry, J. A. (1992). Coupled photosynthesisstomatal conductance model for leaves of $\mathrm{c}_{4}$ plants. Functional Plant Biology, $19(5), 519-538$.

De Kauwe, M. G., Medlyn, B. E., Zaehle, S., Walker, A. P., Dietze, M. C., Hickler, T., ... Norby, R. J. (2013). Forest water use and water use efficiency at elevated co2: a model-data intercomparison at two contrasting temperate 
forest face sites. Global Change Biology, 19(6), 1759-1779. Retrieved from https://onlinelibrary.wiley.com/doi/abs/10.1111/gcb.12164 doi: $10.1111 / \mathrm{gcb} .12164$

Donner, L. J., Wyman, B. L., Hemler, R. S., Horowitz, L. W., Ming, Y., Zhao, M., ... Zeng, F. (2011). The dynamical core, physical parameterizations, and basic simulation characteristics of the atmospheric component am3 of the gfdl global coupled model cm3. Journal of Climate, 24(13), 3484-3519. doi: 10.1175/2011.JCLI3955.1

Emberson, L. D., Simpson, D., Tuovinen, J.-P., Ashmore, M. R., \& Cambridge, H. M. (2000). Towards a model of ozone deposition and stomatal uptake over europe.

Emmons, L. K., Walters, S., Hess, P. G., Lamarque, J. F., Pfister, G. G., Fillmore, D., ... Kloster, S. (2010). Description and evaluation of the Model for Ozone and Related chemical Tracers, version 4 (MOZART-4). Geoscientific Model Development, 3(1), 43-67. doi: 10.5194/gmd-3-43-2010

Erisman, J. W., Van Pul, A., \& Wyers, P. (1994). Parametrization of surface resistance for the quantification of atmospheric deposition of acidifying pollutants and ozone. Atmospheric Environment, 28(16), 2595-2607. doi: 10.1016/1352-2310(94)90433-2

Fan, Y., Meijide, A., Lawrence, D. M., Roupsard, O., Carlson, K. M., Chen, H.Y., ... Knohl, A. (2019). Reconciling canopy interception parameterization and rainfall forcing frequency in the community land model for simulating evapotranspiration of rainforests and oil palm plantations in indonesia. Journal of Advances in Modeling Earth Systems, 11(3), 732-751. doi: 10.1029/2018MS001490

Fang, H., Baret, F., Plummer, S., \& Schaepman-Strub, G. $\quad$ (2019). An overview of global leaf area index (lai): Methods, products, validation, and applications. Reviews of Geophysics, 57(3), 739-799. Retrieved from https:// agupubs.onlinelibrary.wiley.com/doi/abs/10.1029/2018RG000608 doi: 10.1029/2018RG000608

Fang, H., Jiang, C., Li, W., Wei, S., Baret, F., Chen, J. M., ... Zhu, Z. (2013) Characterization and intercomparison of global moderate resolution leaf area index (lai) products: Analysis of climatologies and theoretical uncertainties. Journal of Geophysical Research: Biogeosciences, 118(2), 529-548. doi: $10.1002 /$ jgrg.20051

Fares, S., McKay, M., Holzinger, R., \& Goldstein, A. H. (2010). Ozone fluxes in a pinus ponderosa ecosystem are dominated by non-stomatal processes: Evidence from long-term continuous measurements. Agricultural and Forest Meteorology, 150(3), 420-431. doi: 10.1016/j.agrformet.2010.01.007

Fares, S., Savi, F., Muller, J., Matteucci, G., \& Paoletti, E. Simultaneous measurements of above and below canopy ozone fluxes help partitioning ozone deposition between its various sinks in a mediterranean oak forest. Agricultural and Forest Meteorology, 198-199, 181-191. doi: 10.1016/j.agrformet.2014.08.014

Fares, S., Weber, R., Park, J. H., Gentner, D., Karlik, J., \& Goldstein, A. H. (2012). Ozone deposition to an orange orchard: Partitioning between stomatal and non-stomatal sinks. Environmental Pollution, 169, 258-266. doi: 10.1016/j.envpol.2012.01.030

Farquhar, G. D., von Caemmerer, S., \& Berry, J. A. (1980). A biochemical model of photosynthetic $\mathrm{CO}_{2}$ assimilation in leaves of $\mathrm{c}_{3}$ species. Planta, 149(1), 78-90. doi: $10.1007 / \mathrm{BF} 00386231$

Finkelstein, P. L. (2001). Deposition velocities of $\mathrm{SO}_{2}$ and $\mathrm{O}_{3}$ over agricultural and forest ecosystems. Water, Air, and Soil Pollution, 49-57. doi: 10.1007/978-94 -010-9026-1_6

Finkelstein, P. L., Ellestad, T. G., Clarke, J. F., Meyers, T. P., Schwede, D. B., 
Hebert, E. O., \& Neal, J. A. (2000). Ozone and sulfur dioxide dry deposition to forests: Observations and model evaluation. Journal of Geophysical Research: Atmospheres, 105(D12), 15365-15377. doi: 10.1029/2000jd900185

Fiore, A. M., Dentener, F. J., Wild, O., Cuvelier, C., Schultz, M. G., Hess, P., ... Zuber, A. (2009). Multimodel estimates of intercontinental source-receptor relationships for ozone pollution. Journal of Geophysical Research: Atmospheres, 114(D4). doi: 10.1029/2008JD010816

Fowler, D., Pilegaard, K., Sutton, M., Ambus, P., Raivonen, M., Duyzer, J., ... Erisman, J. (2009). Atmospheric composition change: Ecosystemsatmosphere interactions. Atmospheric Environment, 43(33), 5193-5267. doi: 10.1016/j.atmosenv.2009.07.068

Friedlingstein, P., Cox, P., Betts, R., Bopp, L., von Bloh, W., Brovkin, V., ... others (2006). Climate-carbon cycle feedback analysis: results from the c4mip model intercomparison. Journal of Climate, 19(14), 3337-3353.

Fu, Y., \& Tai, A. P. K. (2015). Impact of climate and land cover changes on tropospheric ozone air quality and public health in East Asia between 1980 and 2010. Atmospheric Chemistry and Physics, 15, 10093-10106. doi: 10.5194/acp-15-10093-2015

Fuentes, J. D., \& Gillespie, T. J. (1992). A gas exchange system to study the effects of leaf surface wetness on the deposition of ozone. Atmospheric Environment, 26 (6), 1165-1173. doi: 10.1016/0960-1686(92)90048-p

Fuentes, J. D., Gillespie, T. J., den Hartog, G., \& Neumann, H. H. (1992). Ozone deposition onto a deciduous forest during dry and wet conditions. Agricultural and Forest Meteorology, 62(1-2), 1-18. doi: 10.1016/0168-1923(92)90002-1

Fumagalli, I., Gruening, C., Marzuoli, R., Cieslik, S., \& Gerosa, G. (2016) Long-term measurements of $\mathrm{no}_{x}$ and $\mathrm{o}_{3}$ soil fluxes in a temperate deciduous forest. Agricultural and Forest Meteorology, 228-229, 205-216. doi: 10.1016/j.agrformet.2016.07.011

Galbally, I., \& Allison, I. (1972). Ozone fluxes over snow surfaces. Journal of Geophysical Research, 77(21), 3946-3949. doi: 10.1029/JC077i021p03946

Galbally, I. E., \& Roy, C. R. (1980). Destruction of ozone at the earth's surface. Quarterly Journal of the Royal Meteorological Society, 106(449), 599-620. doi: 10.1002/qj.49710644915

Ganzeveld, L., Bouwman, L., Stehfest, E., Van Vuuren, D. P., Eickhout, B., \& Lelieveld, J. (2010). Impact of future land use and land cover changes on atmospheric chemistry-climate interactions. Journal of Geophysical Research: Atmospheres, 115(23), 1-18. doi: 10.1029/2010JD014041

Ganzeveld, L., Helmig, D., Fairall, C. W., Hare, J., \& Pozzer, A. Atmosphere-ocean ozone exchange: A global modeling study of biogeochemical, atmospheric, and waterside turbulence dependencies. Global Biogeochemical Cycles, 23(4), 1-16. doi: 10.1029/2008GB003301

Gao, Y., Fu, J. S., Drake, J. B., Lamarque, J. F., \& Liu, Y. (2013). The impact of emission and climate change on ozone in the United States under representative concentration pathways (RCPs). Atmospheric Chemistry and Physics, 13(18), 9607-9621. doi: 10.5194/acp-13-9607-2013

Geddes, J. A., Heald, C. L., Silva, S. J., \& Martin, R. V. ～(2016). Land cover change impacts on atmospheric chemistry: Simulating projected large-scale tree mortality in the United States. Atmospheric Chemistry and Physics, 16 (4), 2323-2340. doi: 10.5194/acp-16-2323-2016

Gerber, S., Hedin, L. O., Oppenheimer, M., Pacala, S. W., \& Shevliakova, E. (2010). Nitrogen cycling and feedbacks in a global dynamic land model. Global Biogeochemical Cycles, 24(1). doi: 10.1029/2008GB003336

Gong, S., Walmsley, J., Barrie, L., \& Hopper, J. (1997). Mechanisms for surface ozone depletion and recovery during polar sunrise. Atmospheric Environment, $31(7), 969-981$. 
Green, J. K., Seneviratne, S. I., Berg, A. M., Findell, K. L., Hagemann, S., Lawrence, D. M., \& Gentine, P. (2019). Large influence of soil moisture on long-term terrestrial carbon uptake. Nature, 565(7740), 476.

Guenther, A., Karl, T., Harley, P., Wiedinmyer, C., Palmer, P., \& Geron, C. (2006). Estimates of global terrestrial isoprene emissions using megan (model of emissions of gases and aerosols from nature). Atmospheric Chemistry and Physics, $6(11), 3181-3210$.

Güsten, H., Heinrich, G., Mönnich, E., Sprung, D., Weppner, J., Ramadan, A. B., ... Hassan, G. K. (1996). On-line measurements of ozone surface fluxes: Part ii. surface-level ozone fluxes onto the sahara desert. Atmospheric Environment, $30(6), 911-918$.

Hardacre, C., Wild, O., \& Emberson, L. (2015). An evaluation of ozone dry deposition in global scale chemistry climate models. Atmospheric Chemistry and Physics, 15 (11), 6419-6436. doi: 10.5194/acp-15-6419-2015

Heald, C. L., \& Geddes, J. A. (2016). The impact of historical land use change from 1850 to 2000 on secondary particulate matter and ozone. Atmospheric Chemistry and Physics, 16 (23), 14997-15010. doi: 10.5194/acp-16-14997-2016

Helmig, D., Cohen, L. D., Bocquet, F., Oltmans, S., Grachev, A., \& Neff, W. (2009). Spring and summertime diurnal surface ozone fluxes over the polar snow at Summit, Greenland. Geophysical Research Letters, 36(8), 1-5. doi: 10.1029/2008GL036549

Helmig, D., Ganzeveld, L., Butler, T., \& Oltmans, S. J. (2007). The role of ozone atmosphere-snow gas exchange on polar, boundary-layer tropospheric ozone-a review and sensitivity analysis. Atmospheric Chemistry and Physics, 7(1), $15-30$.

Helmig, D., Lang, E. K., Bariteau, L., Boylan, P., Fairall, C. W., Ganzeveld, L., ... Pallandt, M. (2012). Atmosphere-ocean ozone fluxes during the TexAQS 2006, STRATUS 2006, GOMECC 2007, GasEx 2008, and AMMA 2008 cruises. Journal of Geophysical Research: Atmospheres, 117(4), 1-15. doi: 10.1029/2011JD015955

Hicks, B., \& Liss, P. S. (1976). Transfer of $\mathrm{SO}_{2}$ and other reactive gases across the air-sea interface. Tellus, 27(4), 348-354.

Hogg, A. (2007). Stomatal and non-stomatal fluxes of ozone, NOx, and NOy to a northern mixed hardwood forest (Unpublished doctoral dissertation). The University of Michigan.

Hogg, A., Uddling, J., Ellsworth, D., Carroll, M. A., Pressley, S., Lamb, B., \& Vogel, C. (2007). Stomatal and non-stomatal fluxes of ozone to a northern mixed hardwood forest. Tellus B, 59(3), 514-525. doi: 10.3402/tellusb.v59i3.17027

Hogrefe, C., Liu, P., Pouliot, G., Mathur, R., Roselle, S., Flemming, J., ... Park, R. J. (2018). Impacts of different characterizations of large-scale background on simulated regional-scale ozone over the continental United States. Atmospheric Chemistry and Physics, 18 (5), 3839-3864. 10.5194/acp-18-3839-2018

Hollaway, M. J., Arnold, S. R., Collins, W. J., Folberth, G., \& Rap, A. (2016). Sensitivity of midnineteenth century tropospheric ozone to atmospheric chemistryvegetation interactions. Journal of Geophysical Research: Atmospheres, 122, 1-22. doi: 10.1002/2016JD025462

Hopper, J., Barrie, L., Silis, A., Hart, W., Gallant, A., \& Dryfhout, H. (1998). Ozone and meteorology during the 1994 polar sunrise experiment. Journal of Geophysical Research: Atmospheres, 103(D1), 1481-1492. doi: 10.1029/97JD02888

HTAP. (2010). Hemispheric transport of air pollution 2010 part a: Ozone and particulate matter, air pollution studies no. 17. New York: United Nations.

Huang, L., McDonald-Buller, E. C., McGaughey, G., Kimura, Y., \& Allen, D. T. (2016). The impact of drought on ozone dry deposition over eastern Texas. At- 
mospheric Environment, 127, 176-186. doi: 10.1016/j.atmosenv.2015.12.022

Humphrey, V., Zscheischler, J., Ciais, P., Gudmundsson, L., Sitch, S., \& Seneviratne, S. I. (2018). Sensitivity of atmospheric co2 growth rate to observed changes in terrestrial water storage. Nature, 560(7720), 628.

Hurtt, G. C., Chini, L. P., Frolking, S., Betts, R. A., Feddema, J., Fischer, G., .. . Wang, Y. P. (2011). Harmonization of land-use scenarios for the period 1500-2100: 600 years of global gridded annual land-use transitions, wood harvest, and resulting secondary lands. Climatic Change, 109(1), 117-161. doi: 10.1007/s10584-011-0153-2

Jarvis, P. G. (1976). The interpretation of the variations in leaf water potential and stomatal conductance found in canopies in the field. Philosophical Transactions of the Royal Society London B, 273, 593-610.

Jensen, N., \& Hummelshøj, P. (1995). Derivation of canopy resistance for water vapour fluxes over a spruce forest, using a new technique for the viscous sublayer resistance. Agricultural and Forest Meteorology, 73(3-4), 339-352. doi: 10.1016/0168-1923(94)05083-i

Jensen, N., \& Hummelshøj, P. (1997). Erratum to "derivation of canopy resistance for water vapour fluxes over a spruce forest, using a new technique for the viscous sublayer resistance" [agricultural and forest meteorology 73 (1995) 339-352]. Agricultural and Forest Meteorology, 85, $289 . \quad$ doi: 10.1016/0168-1923(94)05083-i

John, J. G., Fiore, A. M., Naik, V., Horowitz, L. W., \& Dunne, J. P. (2012). Climate versus emission drivers of methane lifetime against loss by tropospheric oh from 1860-2100. Atmospheric Chemistry and Physics, 12(24), 12021-12036. doi: $10.5194 /$ acp-12-12021-2012

Kavassalis, S. C., \& Murphy, J. G. (2017). Understanding ozone-meteorology correlations: A role for dry deposition. Geophysical Research Letters, 44(6), 2922 2931. doi: 10.1002/2016gl071791

Laisk, A., Kull, O., \& Moldau, H. (1989). Ozone Concentration in Leaf Intercellular Air Spaces Is Close to Zero. Plant Physiology, 90(3), 1163-1167. doi: 10.1104/ pp.90.3.1163

Lamarque, J. F., Kyle, P. P., Meinshausen, M., Riahi, K., Smith, S. J., van Vuuren, D. P., ... Vitt, F. (2011). Global and regional evolution of short-lived radiatively-active gases and aerosols in the representative concentration pathways. Climatic Change, 109(1), 191-212. doi: 10.1007/s10584-011-0155-0

Leuning, R. (1995). A critical appraisal of combined stomatal-photosynthesis model for $\mathrm{C}_{3}$ plants. Plant, Cell \& Environment, 339-355.

Lian, X., Piao, S., Huntingford, C., Li, Y., Zeng, Z., Wang, X., .. o others (2018). Partitioning global land evapotranspiration using cmip5 models constrained by observations. Nature Climate Change, 8(7), 640.

Lin, J.-T., Youn, D., Liang, X.-Z., \& Wuebbles, D. J. (2008). Global model simulation of summertime us ozone diurnal cycle and its sensitivity to pbl mixing, spatial resolution, and emissions. Atmospheric Environment, 42(36), 84708483. doi: 10.1016/j.atmosenv.2008.08.012

Lin, M., Horowitz, L. W., Payton, R., Fiore, A. M., \& Tonnesen, G. (2017). Us surface ozone trends and extremes from 1980 to 2014: quantifying the roles of rising asian emissions, domestic controls, wildfires, and climate. Atmospheric Chemistry and Physics, 17(4), 2943-2970. doi: 10.5194/acp-17-2943-2017

Lin, M., Malyshev, S., Shevliakova, E., Paulot, F., Horowitz, L. W., Fares, S., ... Zhang, L. (2019). Sensitivity of ozone dry deposition to ecosystem-atmosphere interactions: A critical appraisal of observations and simulations. Global Biogeochemical Cycles. doi: 10.1029/2018GB006157

Loubet, B., Cellier, P., Milford, C., \& Sutton, M. A. (2006). A coupled dispersion and exchange model for short-range dry deposition of atmospheric ammonia. Quarterly Journal of the Royal Meteorological Society: A journal of the at- 
mospheric sciences, applied meteorology and physical oceanography, 132(618), 1733-1763.

Luhar, A. K., Galbally, I. E., Woodhouse, M. T., \& Thatcher, M. (2017). An improved parameterisation of ozone dry deposition to the ocean and its impact in a global climate-chemistry model. Atmospheric Chemistry and Physics, 17(5), 3749-3767. doi: 10.5194/acp-17-3749-2017

Martino, M., Lézé, B., Baker, A. R., \& Liss, P. S. (2012). Chemical controls on ozone deposition to water. Geophysical Research Letters, 39(5), 39-43. doi: 10 .1029/2011GL050282

Massman, W. J. (2004). Toward an ozone standard to protect vegetation based on effective dose: a review of deposition resistances and a possible metric. Atmospheric Environment, 38(15), 2323-2337. doi: 10.1016/j.atmosenv.2003.09 .079

Matichuk, R., Tonnesen, G., Luecken, D., Gilliam, R., Napelenok, S. L., Baker, K. R., .. Roselle, S. (2017). Evaluation of the Community Multiscale Air Quality Model for Simulating Winter Ozone Formation in the Uinta Basin. Journal of Geophysical Research: Atmospheres, 122(24), 13,545-13,572. doi: 10.1002/2017JD027057

Meyers, T. P., Finkelstein, P., Clarke, J., Ellestad, T. G., \& Sims, P. F. (1998). A multilayer model for inferring dry deposition using standard meteorological measurements. Journal of Geophysical Research: Atmospheres, 103(D17), 22645-22661. doi: 10.1029/98jd01564

Milly, P. C. D., Malyshev, S. L., Shevliakova, E., Dunne, K. A., Findell, K. L., Gleeson, T., ... Swenson, S. (2014). An Enhanced Model of Land Water and Energy for Global Hydrologic and Earth-System Studies. Journal of Hydrometeorology, 15(5), 1739-1761. doi: 10.1175/JHM-D-13-0162.1

Munger, J. W., Wofsy, S. C., Bakwin, P. S., Fan, S.-M., Goulden, M. L., Daube, B. C., .. Fitzjarrald, D. R. (1996). Atmospheric deposition of reactive nitrogen oxides and ozone in a temperate deciduous forest and a subarctic woodland: 1. measurements and mechanisms. Journal of Geophysical Research: Atmospheres, 101(D7), 12639-12657. doi: 10.1029/96jd00230

Naik, V., Horowitz, L. W., Fiore, A. M., Ginoux, P., Mao, J., Aghedo, A. M., \& Levy II, H. (2013). Impact of preindustrial to present-day changes in shortlived pollutant emissions on atmospheric composition and climate forcing. Journal of Geophysical Research Atmospheres, 118(14), 8086-8110. doi: 10.1002/jgrd.50608

Neirynck, J., \& Verstraeten, A. (2018). Variability of ozone deposition velocity over a mixed suburban temperate forest. Frontiers in Environmental Science, 6, 82. doi: 10.3389 /fenvs.2018.00082

Olson, D. M., Dinerstein, E., Wikramanayake, E. D., Burgess, N. D., Powell, G. V. N., Underwood, E. C., .. Kassem, K. R. $\quad(2001,11)$ Terrestrial Ecoregions of the World: A New Map of Life on Earth: A new global map of terrestrial ecoregions provides an innovative tool for conserving biodiversity. BioScience, 51(11), 933-938. doi: 10.1641/0006-3568(2001)051[0933: TEOTWA]2.0.CO;2

Padro, J. (1993). Seasonal contrasts in modelled and observed dry deposition velocities of $\mathrm{O}_{3}, \mathrm{SO}_{2}$ and $\mathrm{no}_{2}$ over three surfaces. Atmospheric Environment, $27(6)$, 807-814. doi: 10.1016/0960-1686(93)90002-G

Padro, J., Neumann, H. H., \& den Hartog, G. (1992). Modelled and observed dry deposition velocity of ozone above a deciduous forest in the winter. Atmospheric Environment, 26(5).

Paulot, F., Ginoux, P., Cooke, W. F., Donner, L. J., Fan, S., Lin, M. Y., ... Horowitz, L. W. (2016). Sensitivity of nitrate aerosols to ammonia emissions and to nitrate chemistry: Implications for present and future nitrate optical depth. Atmospheric Chemistry and Physics, 16(3), 1459-1477. doi: 
10.5194/acp-16-1459-2016

Paulot, F., Malyshev, S., Nguyen, T., Crounse, J. D., Shevliakova, E., \& Horowitz, L. W. (2018). Representing sub-grid scale variations in nitrogen deposition associated with land use in a global earth system model: implications for present and future nitrogen deposition fluxes over north america. Atmospheric Chemistry and Physics Discussions, 2018, 1-26. doi: 10.5194/acp-2018-572

Pleijel, H., Karlsson, G. P., Danielsson, H., \& Sellden, G. (1995). Surface wetness enhances ozone deposition to a pasture canopy. Atmospheric Environment, 29(22), 3391-3393.

Pleim, J., \& Ran, L. (2011). Surface flux modeling for air quality applications. Atmosphere, 2(3), 271-302. doi: 10.3390/atmos2030271

Potier, E., Loubet, B., Durand, B., Flura, D., Bourdat-Deschamps, M., Ciuraru, R., \& Ogée, J. (2017). Chemical reaction rates of ozone in water infusions of wheat, beech, oak and pine leaves of different ages. Atmospheric Environment, 151, 176-187. doi: 10.1016/j.atmosenv.2016.11.069

Potier, E., Ogée, J., Jouanguy, J., Lamaud, E., Stella, P., Personne, E., ... Loubet, B. (2015). Multilayer modelling of ozone fluxes on winter wheat reveals large deposition on wet senescing leaves. Agricultural and Forest Meteorology, 211-212, 58-71. doi: 10.1016/j.agrformet.2015.05.006

Rannik, Ü., Altimir, N., Mammarella, I., Bäck, J., Rinne, J., Ruuskanen, T. M., ... Kulmala, M. (2012). Ozone deposition into a boreal forest over a decade of observations: evaluating deposition partitioning and driving variables. Atmospheric Chemistry and Physics, 12(24), 12165-12182. doi: 10.5194/acp-12-12165-2012

Rasmussen, D. J., Fiore, A. M., Naik, V., Horowitz, L. W., McGinnis, S. J., \& Schultz, M. G. (2012). Surface ozone-temperature relationships in the eastern US: A monthly climatology for evaluating chemistry-climate models. Atmospheric Environment, 47, 142-153. doi: 10.1016/j.atmosenv.2011.11.021

Riahi, K., Rao, S., Krey, V., Cho, C., Chirkov, V., Fischer, G., .. Rafaj, P. (2011). Rcp 8.5 - a scenario of comparatively high greenhouse gas emissions. Climatic Change, 109(1-2), 33.

Rieder, H. E., Fiore, A. M., Clifton, O. E., Correa, G., Horowitz, L. W., \& Naik, V. (2018). Combining model projections with site-level observations to estimate changes in distributions and seasonality of ozone in surface air over the u.s.a. Atmospheric Environment. doi: 10.1016/j.atmosenv.2018.07.042

Sarwar, G., Kang, D., Foley, K., Schwede, D., Gantt, B., \& Mathur, R. (2016). Technical note: Examining ozone deposition over seawater. Atmospheric Environment, 141, 255-262. doi: 10.1016/j.atmosenv.2016.06.072

Schultz, M. G., Schröder, S., Lyapina, O., Cooper, O., Galbally, I., Petropavlovskikh, I., ... Zhiqiang, M. (2017). Tropospheric Ozone Assessment Report: Database and Metrics Data of Global Surface Ozone Observations. Elementa Science of the Anthropocene, 5(0), 58. doi: 10.1525/elementa.244

Schultz, M. G., Schröder, S., Lyapina, O., Cooper, O. R., Galbally, I., Petropavlovskikh, I., ... Zhiqiang, M. (2017). Tropospheric Ozone Assessment Report, links to Global surface ozone datasets [data set]. PANGAEA. Retrieved from https://doi.org/10.1594/PANGAEA.876108 doi: 10.1594/PANGAEA.876108

Shevliakova, E., Pacala, S. W., Malyshev, S., Hurtt, G. C., Milly, P. C., Caspersen, J. P., .. Crevoisier, C. (2009). Carbon cycling under 300 years of land use change: importance of the secondary vegetation sink. Global Biogeochemical Cycles, 23(2), 1-16. doi: 10.1029/2007GB003176

Silva, S. J., \& Heald, C. L. (2018). Investigating dry deposition of ozone to vegetation. Journal of Geophysical Research: Atmospheres, 123(1), 559-573. doi: 10 $.1002 / 2017 j d 027278$

Sitch, S., Smith, B., Prentice, I. C., Arneth, A., Bondeau, A., Cramer, W., ... 
Venevsky, S. (2003). Evaluation of ecosystem dynamics, plant geography and terrestrial carbon cycling in the lpj dynamic global vegetation model. Global Change Biology, 9(2), 161-185. doi: 10.1046/j.1365-2486.2003.00569.x Smith, N. G., Malyshev, S. L., Shevliakova, E., Kattge, J., \& Dukes, J. S. (2016). Foliar temperature acclimation reduces simulated carbon sensitivity to climate. Nature Climate Change, 6(4), 407.

Smith, W. K., Reed, S. C., Cleveland, C. C., Ballantyne, A. P., Anderegg, W. R., Wieder, W. R., ... Running, S. W. (2016). Large divergence of satellite and earth system model estimates of global terrestrial co 2 fertilization. Nature Climate Change, 6(3), 306.

Solberg, S., Hov, Ø., Søvde, A., Isaksen, I. S. A., Coddeville, P., De Backer, H., ... Uhse, K. (2008). European surface ozone in the extreme summer 2003. Journal of Geophysical Research: Atmospheres, 113(D7).

Stella, P., Loubet, B., de Berranger, C., Charrier, X., Ceschia, E., Gerosa, G., ... Ciuraru, R. (2019). Soil ozone deposition: Dependence of soil resistance to soil texture. Atmospheric Environment, 199, 202 - 209. doi: https://doi.org/10.1016/j.atmosenv.2018.11.036

Stella, P., Loubet, B., Lamaud, E., Laville, P., \& Cellier, P. (2011). Ozone deposition onto bare soil: A new parameterisation. Agricultural and Forest Meteorology, 151 (6), 669-681. doi: 10.1016/j.agrformet.2011.01.015

Stella, P., Personne, E., Loubet, B., Lamaud, E., Ceschia, E., Béziat, P., .. Cellier, P. (2011). Predicting and partitioning ozone fluxes to maize crops from sowing to harvest: The Surfatm- $\mathrm{O}_{3}$ model. Biogeosciences, 8(10), 2869-2886. doi: $10.5194 /$ bg-8-2869-2011

Stocker, D. W., Zeller, K. F., \& Stedman, D. H. (1995). $\quad \mathrm{O}_{3}$ and $\mathrm{NO}_{2}$ fluxes over snow measured by eddy correlation. Atmospheric Environment, 29(11), 1299 1305. doi: 10.1016/1352-2310(94)00337-K

Sulman, B. N., Shevliakova, E., Brzostek, E. R., Kivlin, S. N., Malyshev, S., Menge, D. N., \& Zhang, X. (2019). Diverse mycorrhizal associations enhance terrestrial c storage in a global model. Global Biogeochemical Cycles, 33(4), 501-523. doi: 10.1029/2018GB005973

Sun, S., Moravek, A., Trebs, I., Kesselmeier, J., \& Sörgel, M. (2016). Investigation of the influence of liquid surface films on $\mathrm{O}_{3}$ and pan deposition to plant leaves coated with organic/inorganic solution. Journal of Geophysical Research: Atmospheres, 121 (23), 14,239-14,256. doi: 10.1002/2016jd025519

Terrer, C., Vicca, S., Hungate, B. A., Phillips, R. P., \& Prentice, I. C. (2016). Mycorrhizal association as a primary control of the co2 fertilization effect. Science, 353(6294), 72-74.

Tilmes, S., Lamarque, J. F., Emmons, L. K., Conley, A., Schultz, M. G., Saunois, M., ... Tarasick, D. (2012). Technical Note: Ozonesonde climatology between 1995 and 2011: Description, evaluation and applications. Atmospheric Chemistry and Physics, 12(16), 7475-7497. doi: 10.5194/acp-12-7475-2012

Trail, M., Tsimpidi, A. P., Liu, P., Tsigaridis, K., Hu, Y., Nenes, A., .. R Russell, A. G. (2015). Reforestation and crop land conversion impacts on future regional air quality in the Southeastern U.S. Agricultural and Forest Meteorology, 209-210, 78-86. doi: 10.1016/j.agrformet.2015.05.001

Travis, K. R., \& Jacob, D. J. (2019). Systematic bias in evaluating chemical transport models with maximum daily $8 \mathrm{~h}$ average (mda8) surface ozone for air quality applications: a case study with geos-chem v9.02. Geoscientific Model Development, 12(8), 3641-3648. Retrieved from https://www.geosci-model -dev.net/12/3641/2019/ doi: 10.5194/gmd-12-3641-2019

Travis, K. R., Jacob, D. J., Fisher, J. A., Kim, P. S., Marais, E. A., Zhu, L., ... Zhou, X. (2016). Why do models overestimate surface ozone in the southeast united states? Atmospheric Chemistry and Physics, 16(21), 13561-13577. doi: 10.5194/acp-16-13561-2016 
Turnipseed, A. A., Burns, S. P., Moore, D. J. P., Hu, J., Guenther, A. B., \& Monson, R. K. (2009). Controls over ozone deposition to a high elevation subalpine forest. Agricultural and Forest Meteorology, 149(9), 1447-1459. doi: 10.1016/j.agrformet.2009.04.001

Van Pul, W. A. J., \& Jacobs, A. F. G. (1994). The conductance of a maize crop and the underlying soil to ozone under various environmental conditions. Boundary-Layer Meteorology, 69, 83-99.

van Vuuren, D. P., Edmonds, J., Kainuma, M., Riahi, K., Thomson, A., Hibbard, K., ... Rose, S. K. (2011). The representative concentration pathways: An overview. Climatic Change, 109(1), 5-31. doi: 10.1007/s10584-011-0148-z

Walker, T. W. (2014). Applications of Adjoint Modelling in Chemical Composition: Studies of Tropospheric Ozone at Middle and High Northern Latitudes (Unpublished doctoral dissertation). University of Toronto.

Wang, D., Hinckley, T. M., Cumming, A. B., \& Braatne, J. (1995). A comparison of measured and modeled ozone uptake into plant leaves. Environmental Pollution, 89(3), 247-254. doi: 10.1016/0269-7491(94)00078-R

Wang, Y., Jacob, D. J., \& Logan, J. A. (1998). Global simulation of tropospheric $\mathrm{O}_{3}$-NOx-hydrocarbon chemistry: 1. Model formulation. Journal of Geophysical Research: Atmospheres, 103, 10713-10725. doi: 10.1029/98JD00158

Weng, E. S., Malyshev, S., Lichstein, J. W., Farrior, C. E., Dybzinski, R., Zhang, T., .. Pacala, S. W. (2015). Scaling from individual trees to forests in an Earth system modeling framework using a mathematically tractable model of height-structured competition. Biogeosciences, 12(9), 2655-2694. doi: 10.5194/bg-12-2655-2015

Wesely, M. L. (1989). Parameterization of surface resistance to gaseous dry deposition in regional-scale numerical model. Atmospheric Environment, 23(6), 1293-1304.

Wesely, M. L., Cook, D. R., \& Williams, R. M. (1981). Field measurements of small ozone fluxes to snow, wet bare soil, and lake water. Boundary-Layer Meteorology, 20, 1293-1304.

Wesely, M. L., \& Hicks, B. B. (1977). Some factors that affect the deposition rates of sulfur dioxide and similar gases on vegetation. the Air Pollution Control Association, 27(11), 1110-1116.

Journal of 00022470.1977.10470534

Wieder, W. R., Cleveland, C. C., Smith, W. K., \& Todd-Brown, K. (2015). Future productivity and carbon storage limited by terrestrial nutrient availability. $\mathrm{Na}$ ture Geoscience, 8(6), 441.

Wild, O. (2007). Modelling the global tropospheric ozone budget: exploring the variability in current models. Atmospheric Chemistry and Physics, 7(10), 26432660. doi: 10.5194/acp-7-2643-2007

Wong, A. Y. H., Geddes, J. A., Tai, A. P. K., \& Silva, S. J. (2019). Importance of dry deposition parameterization choice in global simulations of surface ozone. Atmospheric Chemistry and Physics, 19(22), 14365-14385. Retrieved from https://www .atmos-chem-phys.net/19/14365/2019/ doi: 10.5194/acp-19-14365-2019

Wu, S., Mickley, L. J., Kaplan, J. O., \& Jacob, D. J. (2012). Impacts of changes in land use and land cover on atmospheric chemistry and air quality over the 21st century. Atmospheric Chemistry and Physics, 12(3), 1597-1609. doi: 10.5194/acp-12-1597-2012

Wu, Z., Schwede, D. B., Vet, R., Walker, J. T., Shaw, M., Staebler, R., \& Zhang, L. (2018). Evaluation and intercomparison of five north american dry deposition algorithms at a mixed forest site. Journal of Advances in Modeling Earth Systems, 10(7), 1571-1586. Retrieved from https:// agupubs.onlinelibrary.wiley.com/doi/abs/10.1029/2017MS001231 doi: 10.1029/2017MS001231 
Wu, Z., Staebler, R., Vet, R., \& Zhang, L. (2016). Dry deposition of $\mathrm{O}_{3}$ and $\mathrm{SO}_{2}$ estimated from gradient measurements above a temperate mixed forest. Environmental Pollution, 210, 202-210. doi: 10.1016/j.envpol.2015.11.052

Yuan, W., Zheng, Y., Piao, S., Ciais, P., Lombardozzi, D., Wang, Y., ... Yang, S. (2019). Increased atmospheric vapor pressure deficit reduces global vegetation growth. Science Advances, 5(8). doi: 10.1126/sciadv.aax1396

Zhang, L., Brook, J. R., \& Vet, R. (2002). On ozone dry deposition - with emphasis on non-stomatal uptake and wet canopies. Atmospheric Environment, 36(30), 4787-4799. doi: 10.1016/s1352-2310(02)00567-8

Zhang, L., Brook, J. R., \& Vet, R. (2003). A revised parameterization for gaseous dry deposition in air-quality models. Atmospheric Chemistry and Physics, 3(6), 2067-2082. doi: 10.5194/acp-3-2067-2003 
Harvard Forest $[42.5 \mathrm{~N},-72.2 \mathrm{E}]$

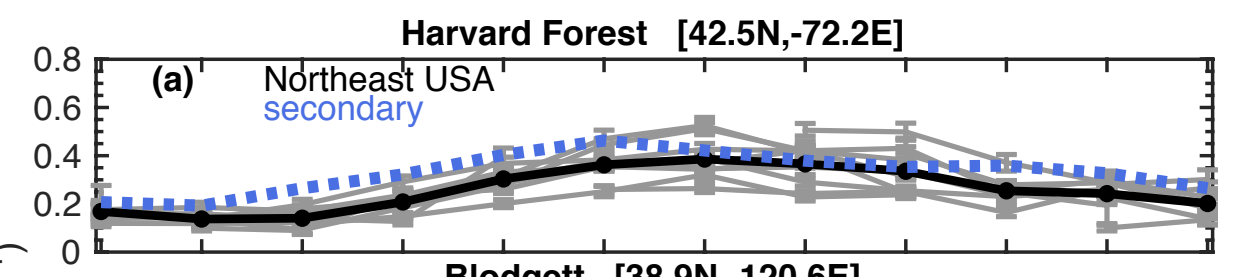
$\simeq 0$

क 0

ह 0.6 겅 0.4

$\stackrel{0}{>}$

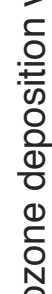

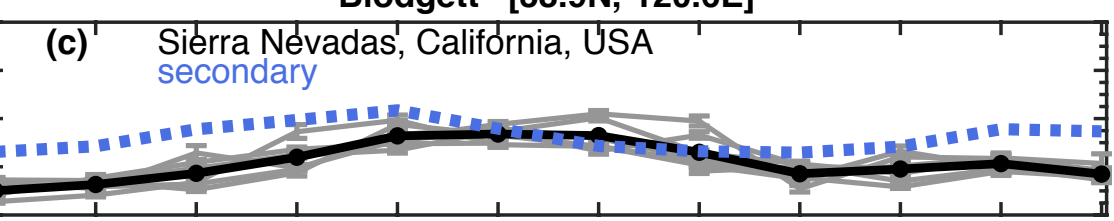

Castelporziano [41.4N,12.2E]

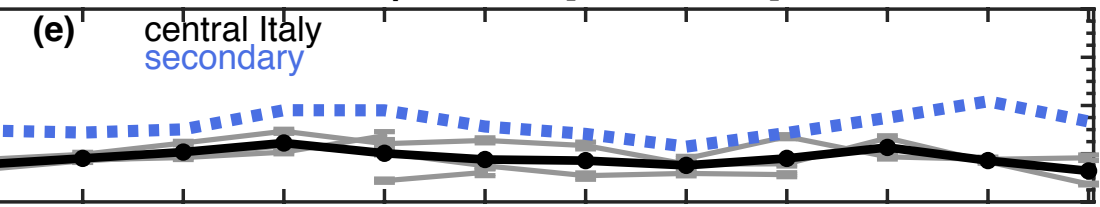
Hyytiälä [61.0N,24.0E] (g) ${ }^{\prime}$ soluthern'Finland

Tremintum 0
UMBS Prophet $[45.5 \mathrm{~N},-84.7 \mathrm{E}]$

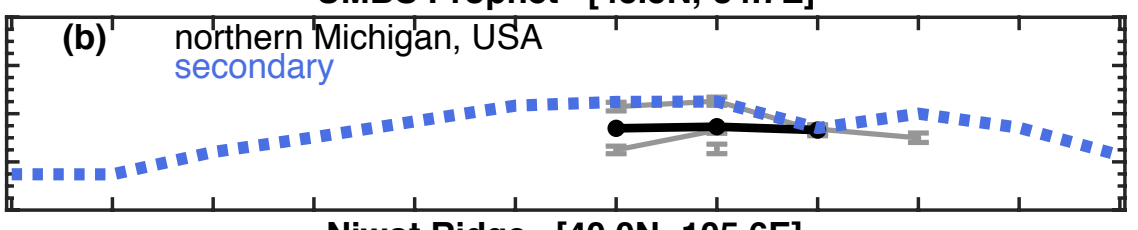

Niwot Ridge [40.0N,-105.6E]
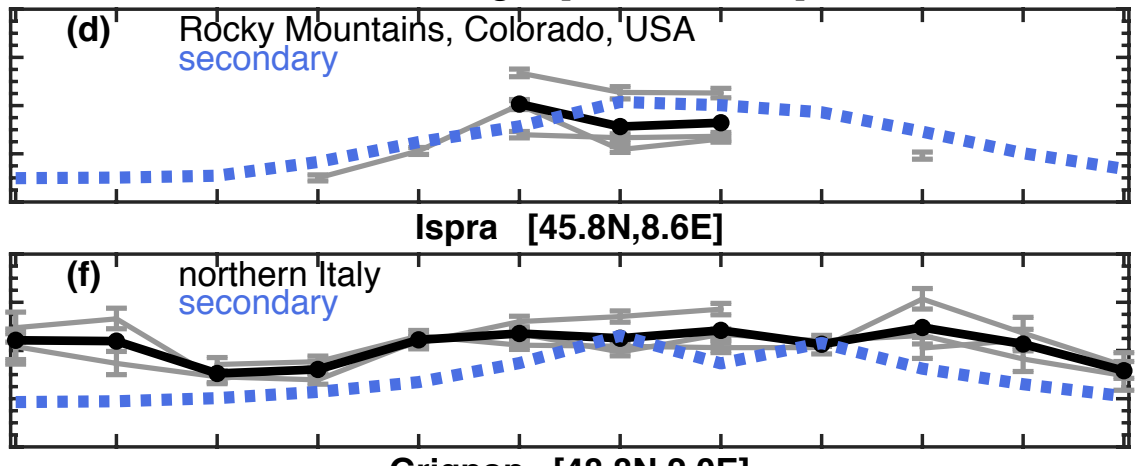
Grignon [48.8N,2.0E]

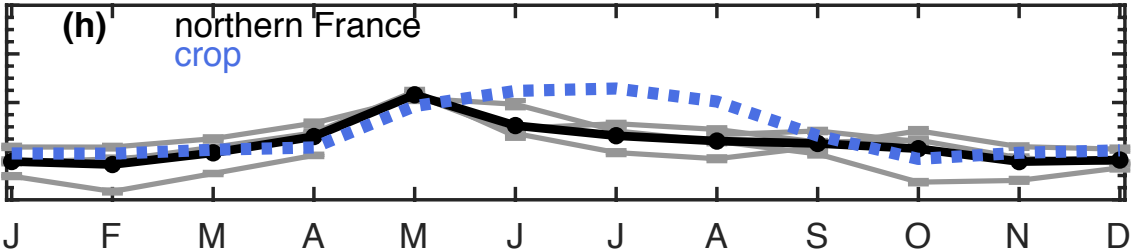
months months 
Figure 2.
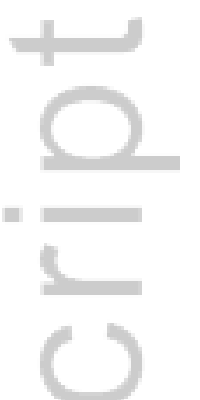

$\infty$
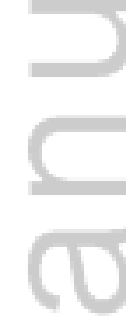

This article is protected by copyright. All rights reserved. 

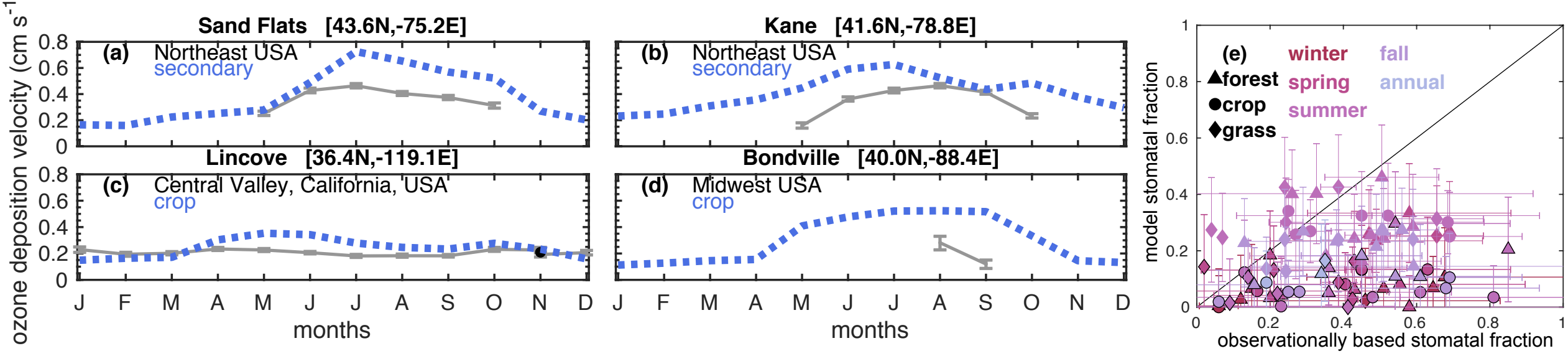
DJF 2010s dynamic-static surface ozone

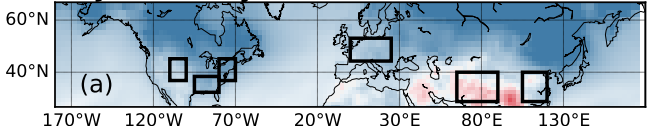

DJF 2010s dynamic-static $\mathbf{v}_{d}$

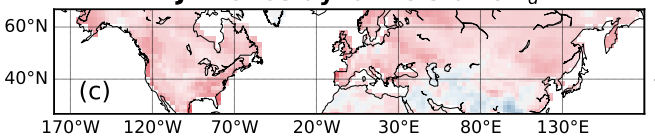

DJF 2090s-2010s static surface ozone

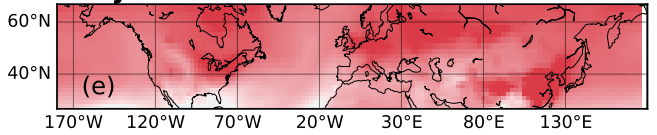

DJF 2090s-2010s dynamic surface ozone

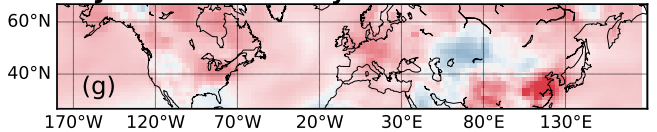

DJF 2090s-2010s dynamic $v_{d}$

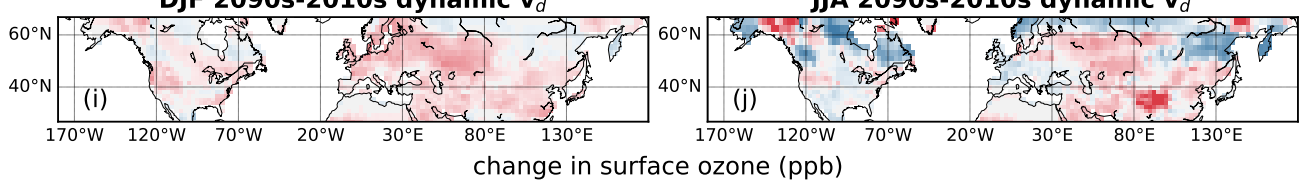

-15 This -10 article is protected by copyright. All right ${ }^{-5}$ ts reserved.
JJA 2010s dynamic-static surface ozone

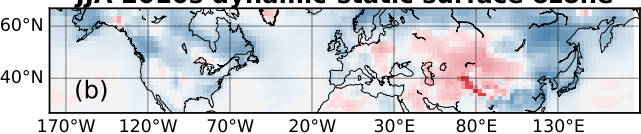

JJA 2010s dynamic-static $\mathbf{v}_{d}$

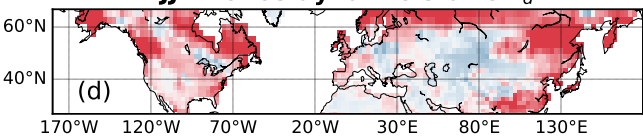

JJA 2090s-2010s static surface ozone

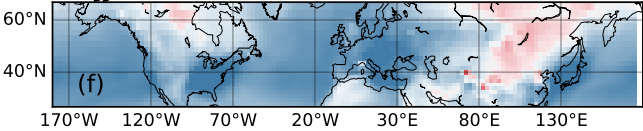

JJA 2090s-2010s dynamic surface ozone

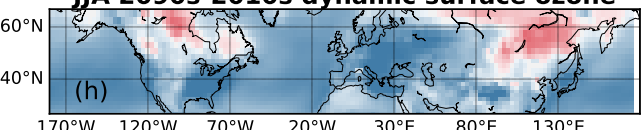

JJA 2090s-2010s dynamic $v_{d}$ 0.4 change in $\mathrm{v}_{d}\left(\mathrm{~cm} \mathrm{~s}^{-1}\right)$ 
DJF 2010s dynamic

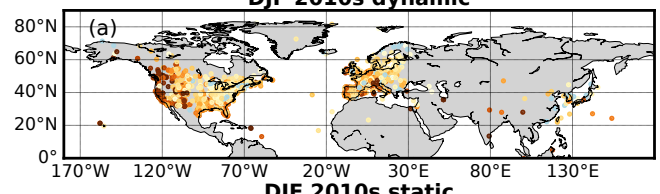

DJF 2010s static

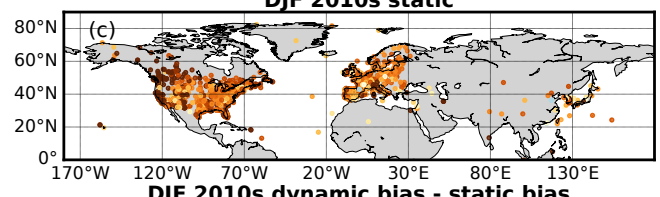

DJF 2010s dynamic bias - static bias
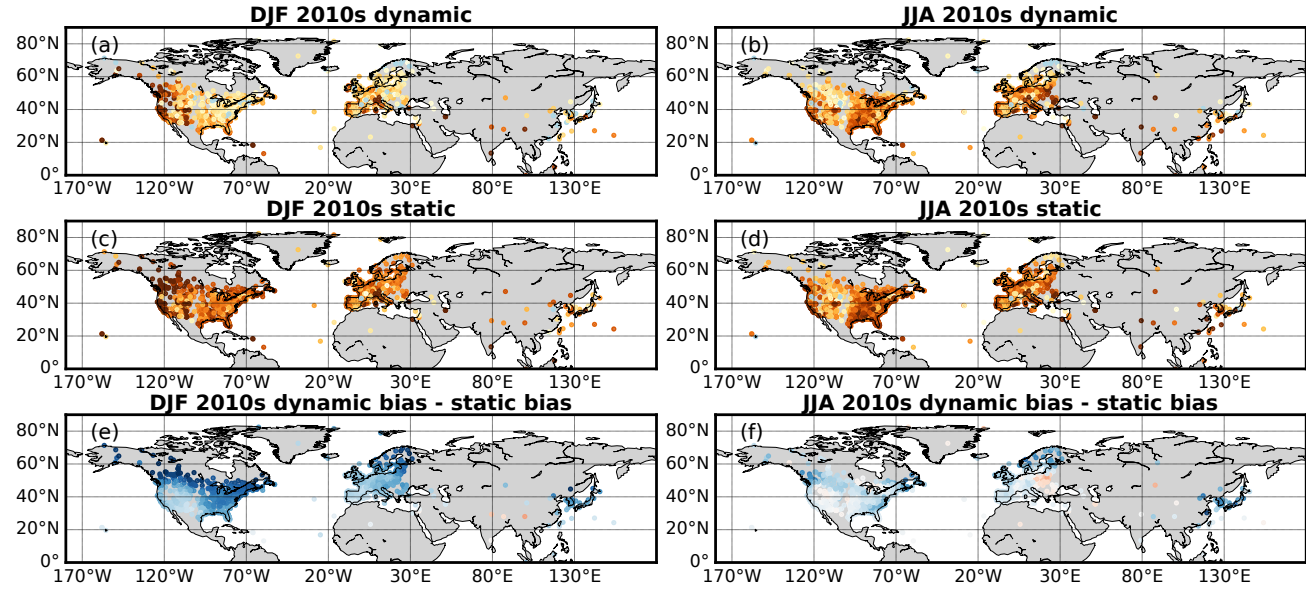

JJA 2010s static

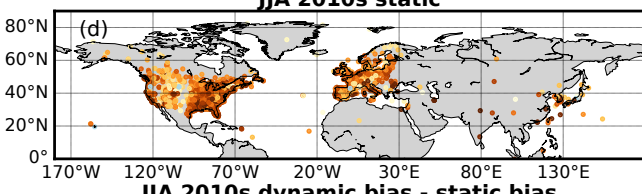

JJA 2010s dynamic bias - static bias

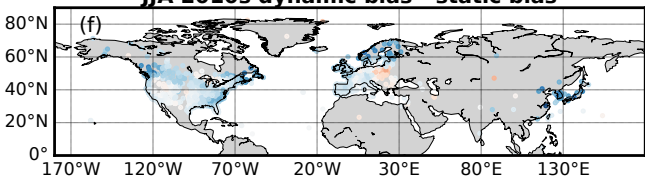

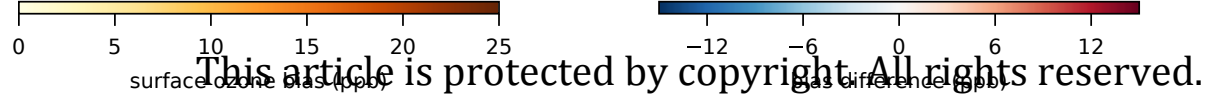


Figure 5.
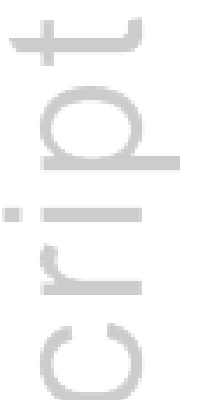

$\infty$
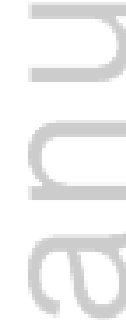

This article is protected by copyright. All rights reserved. 
DJF 2010s dry and wet cuticular uptake

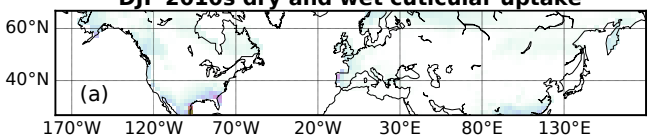

DJF 2010s stem uptake

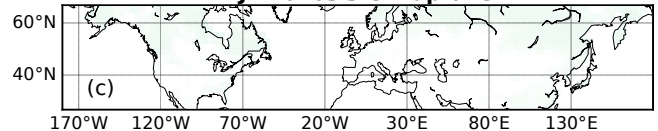

DJF 2010s snow uptake to cuticles and ground

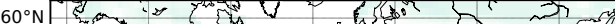

$40^{\circ} \mathrm{N}$

(e)

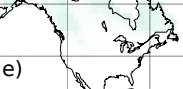

$170^{\circ} \mathrm{W} \quad 120^{\circ} \mathrm{W} \quad 70^{\circ} \mathrm{W} \quad 20^{\circ} \mathrm{W}$

DJF 2010s dry ground uptake

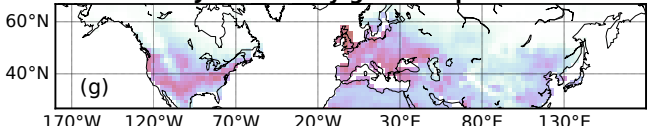

JJA 2010s dry cuticular uptake

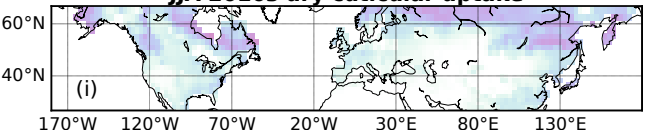

JJA 2010s wet cuticular uptake

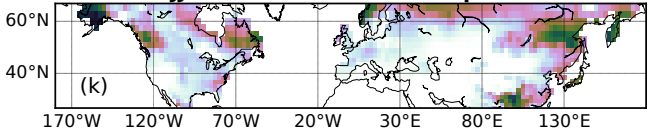

JJA 2010s stomatal uptake

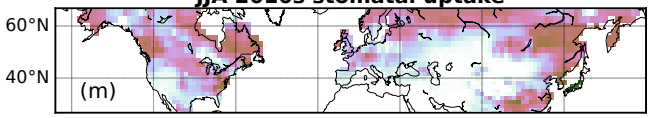

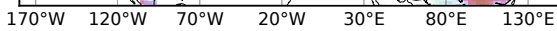

JJA 2010s dry ground uptake

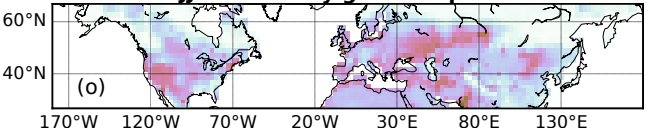

$\begin{array}{lllllll}170^{\circ} \mathrm{W} & 120^{\circ} \mathrm{W} & 70^{\circ} \mathrm{W} & 20^{\circ} \mathrm{W} & 30^{\circ} \mathrm{E} & 80^{\circ} \mathrm{E} & 130^{\circ} \mathrm{E}\end{array}$

$\begin{array}{lllllll}0.0 & 0.1 & 0.2 & 0.3 & 0.4 & 0.5 & 0.6\end{array}$

effective conductance $\left(\mathrm{cm} \mathrm{s}^{-1}\right)$
DJF 2090s-2010s dry and wet cuticular uptake

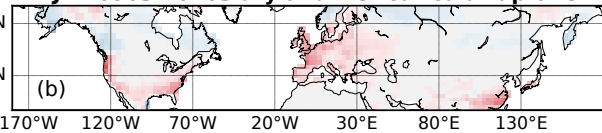

DJF 2090s-2010s stem uptake

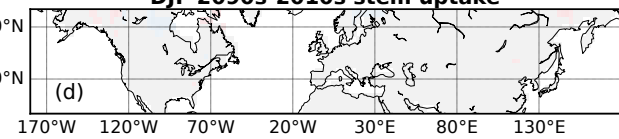

DJF 2090s-2010s snow uptake to cuticles and ground

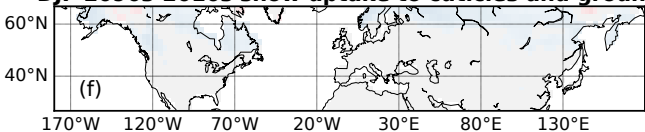

DJF 2090s-2010s dry ground uptake

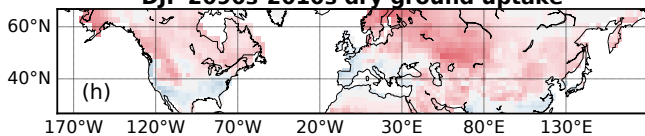

JJA 2090s-2010s dry cuticular uptake

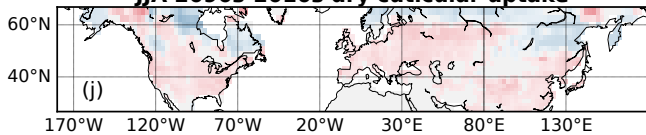

JJA 2090s-2010s wet cuticular uptake

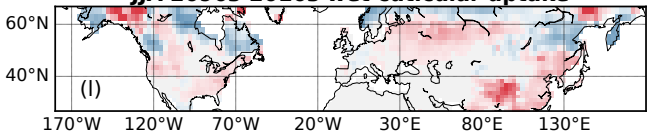

JJA 2090s-2010s stomatal uptake

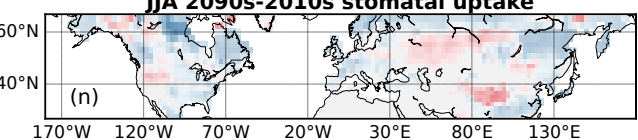

JJA 2090s-2010s dry ground uptake

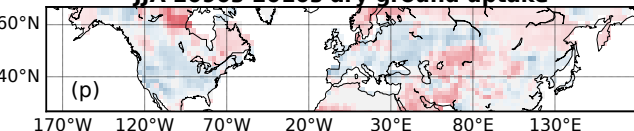

$\begin{array}{lllllll}170^{\circ} \mathrm{W} & 120^{\circ} \mathrm{W} & 70^{\circ} \mathrm{W} & 20^{\circ} \mathrm{W} & 30^{\circ} \mathrm{E} & 80^{\circ} \mathrm{E} & 130^{\circ} \mathrm{E}\end{array}$

$\begin{array}{lllllll}-0.3 & -0.2 & -0.1 & 0.0 & 0.1 & 0.2 & 0.3\end{array}$

change in effective conductance $\left(\mathrm{cm} \mathrm{s}^{-1}\right)$ 
NE US [36-46ㅇ N,70-80 W] SE US [30-38 N,80-95 W] IMW US [36-46 $N, 100-110 \circ$ W]
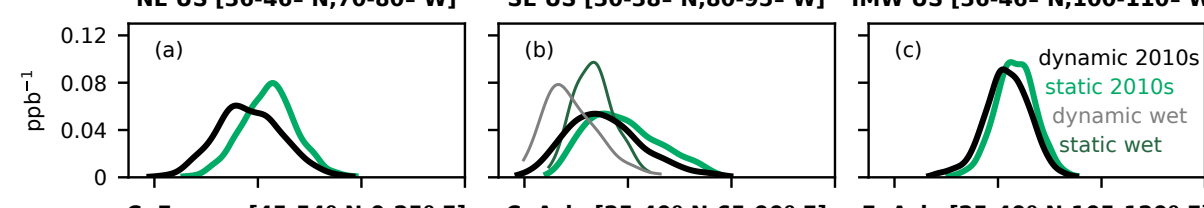

JA 2010s dry-cuticular uptake

C. Europe [45-54 N,0-25 E] C. Asia [25-40 N,65-90 E] E. Asia [25-40 N,105-120 E]
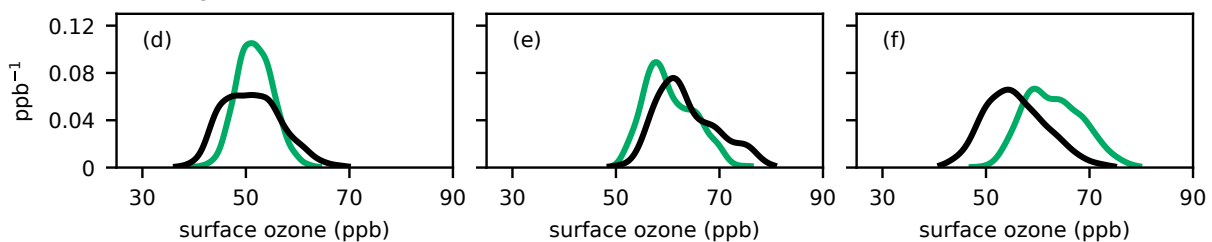

JJA 2010s -r(v $v_{d}$,surface ozone)
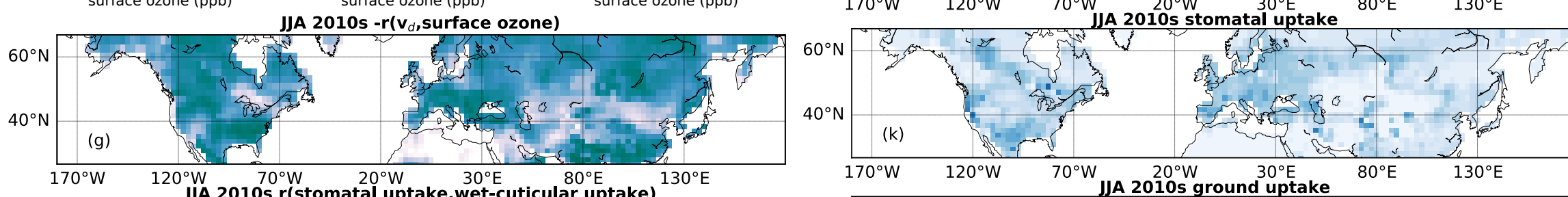
A 2010s r(stomatal uptake, wet-cuticular uptake)
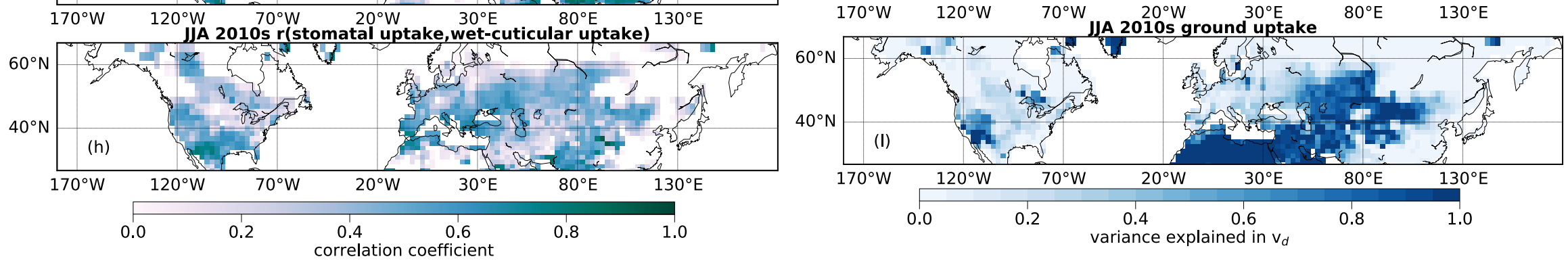
Harvard Forest $[42.5 \mathrm{~N},-72.2 \mathrm{E}]$

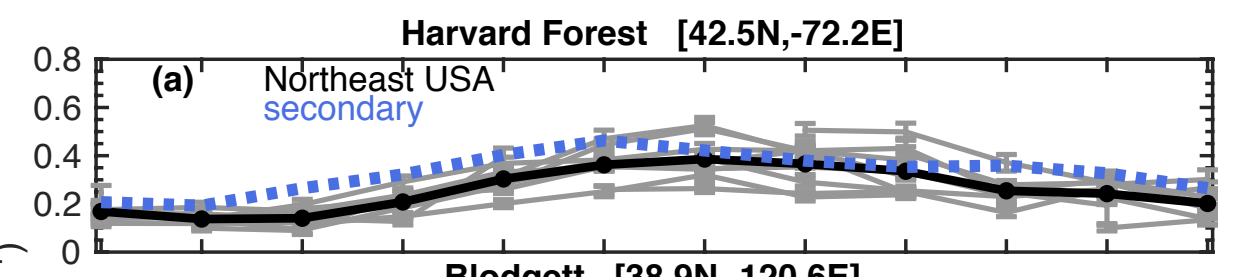
$\simeq 0$

क 0

ह 0.6 겅 0.4

$\stackrel{0}{>}$

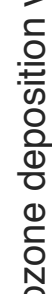

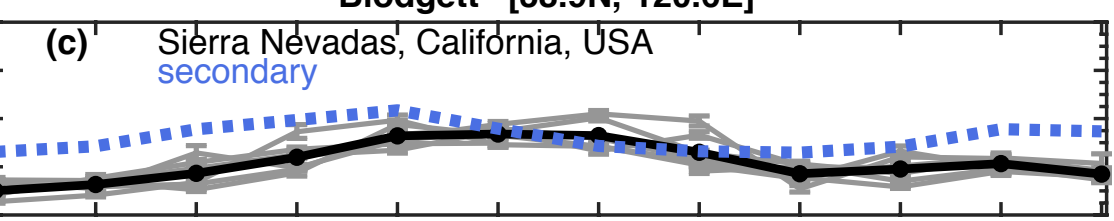

Castelporziano [41.4N,12.2E]

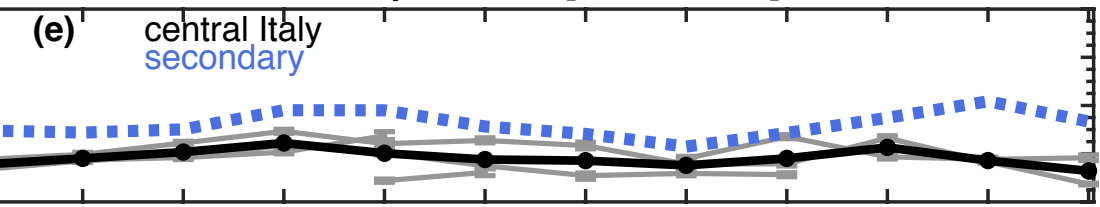
Hyytiälä [61.0N,24.0E] (g) ${ }^{\prime}$ soluthern'Finland

Tremintum 0
UMBS Prophet $[45.5 \mathrm{~N},-84.7 \mathrm{E}]$

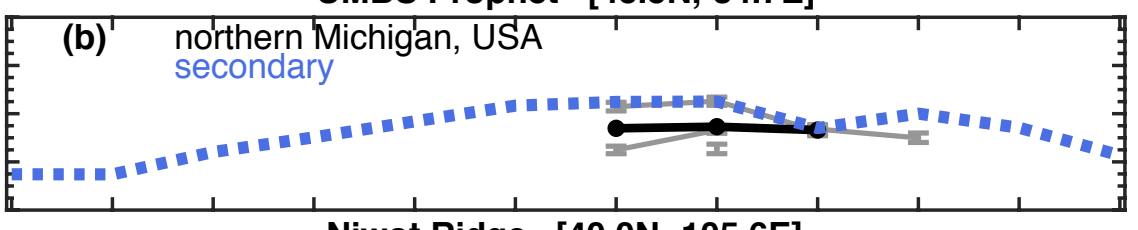

Niwot Ridge [40.0N,-105.6E]
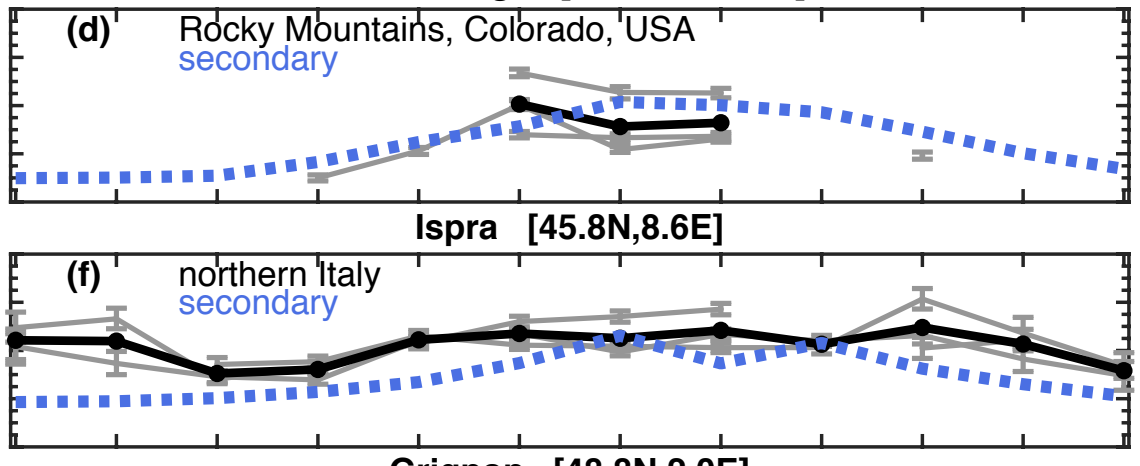
Grignon [48.8N,2.0E]

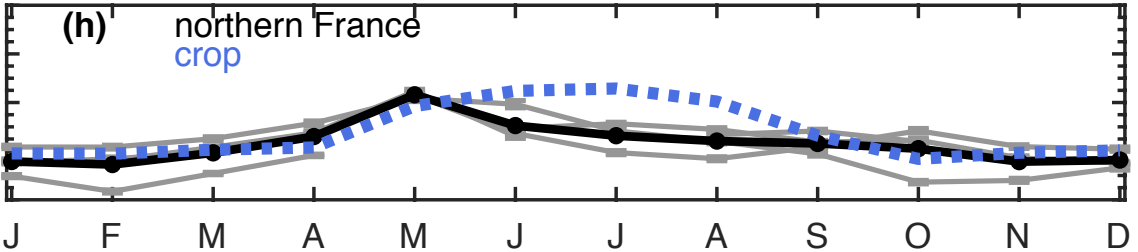
months months 

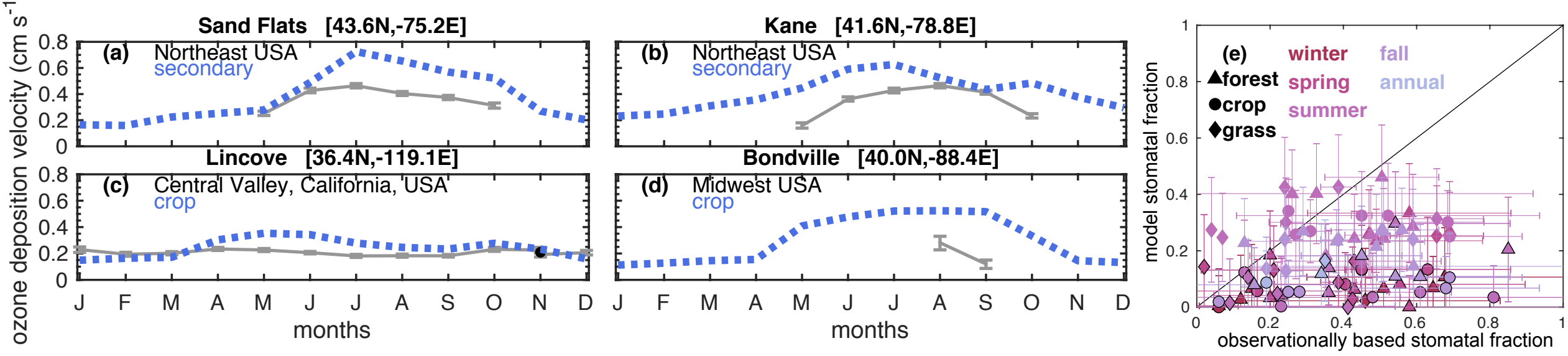
DJF 2010s dynamic-static surface ozone

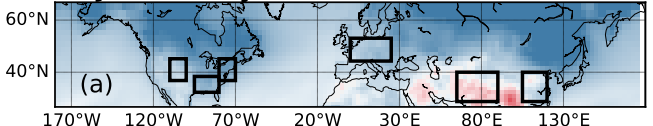

DJF 2010s dynamic-static $\mathbf{v}_{d}$

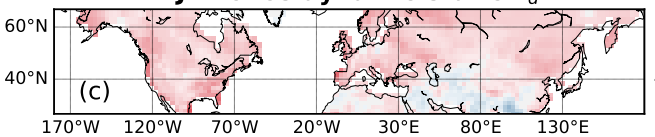

DJF 2090s-2010s static surface ozone

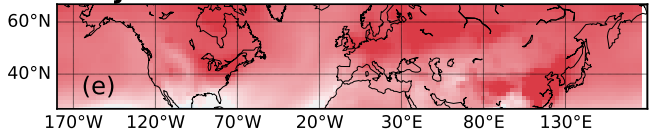

DJF 2090s-2010s dynamic surface ozone

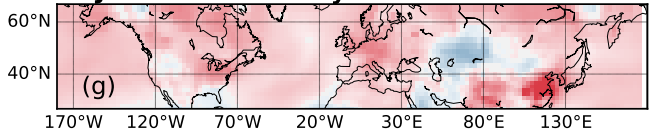

DJF 2090s-2010s dynamic $v_{d}$

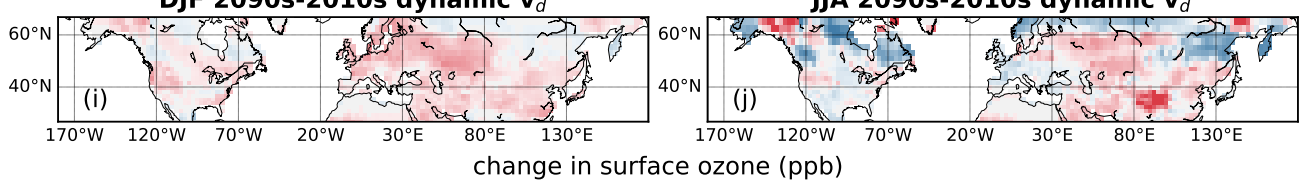

-15 This -10 article is protected by copyright. All right ${ }^{-5}$ ts reserved.
JJA 2010s dynamic-static surface ozone

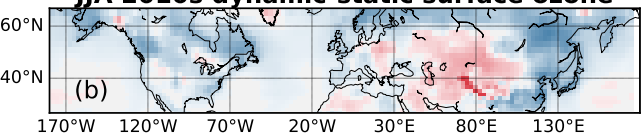

JJA 2010s dynamic-static $\mathbf{v}_{d}$

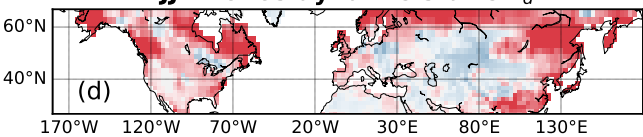

JJA 2090s-2010s static surface ozone

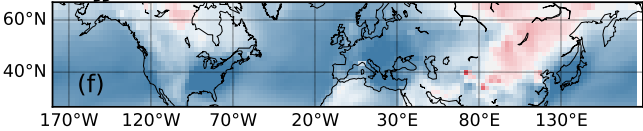

JJA 2090s-2010s dynamic surface ozone

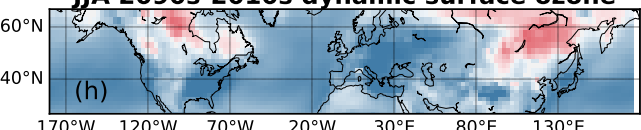

JJA 2090s-2010s dynamic $v_{d}$ 0.4 change in $\mathrm{v}_{d}\left(\mathrm{~cm} \mathrm{~s}^{-1}\right)$ 
DJF 2010s dynamic

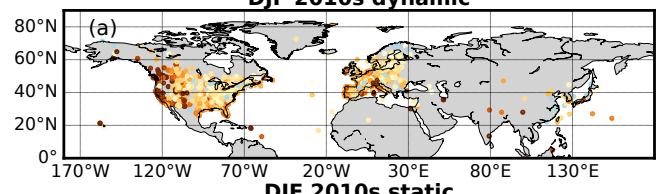

DJF 2010s static

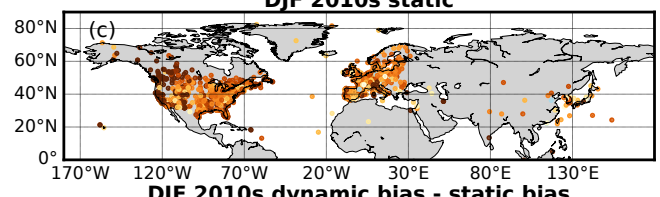

DJF 2010s dynamic bias - static bias
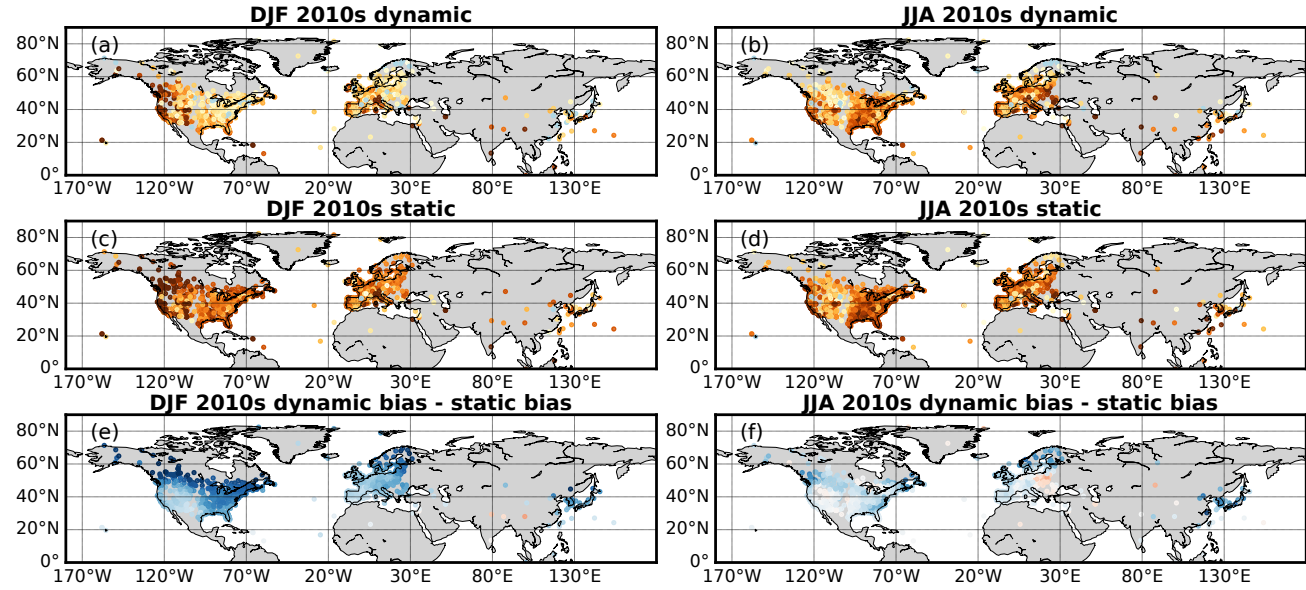

JJA 2010s static

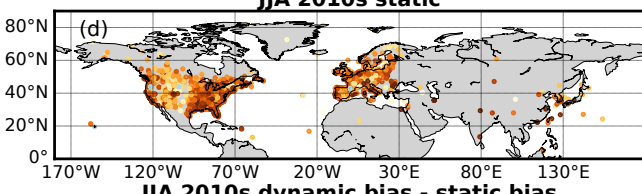

JJA 2010s dynamic bias - static bias

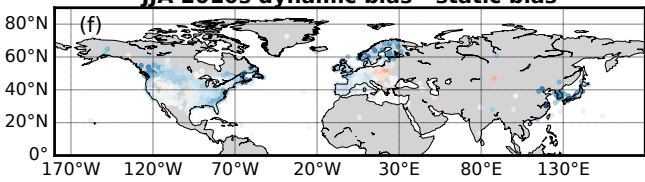

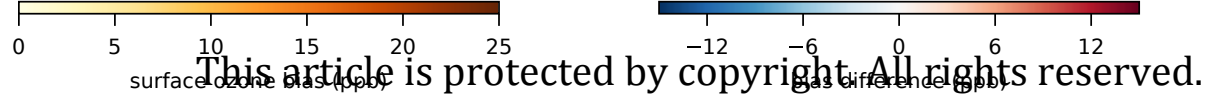


DJF 2010s dry and wet cuticular uptake

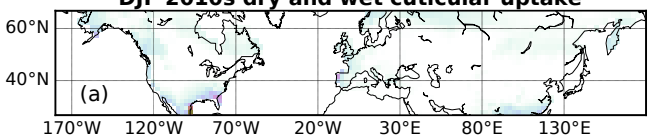

DJF 2010s stem uptake

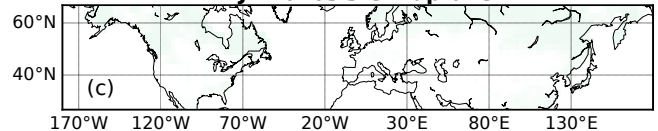

DJF 2010s snow uptake to cuticles and ground

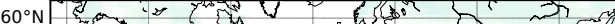

$40^{\circ} \mathrm{N}$

(e)

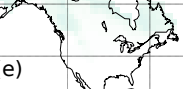

$170^{\circ} \mathrm{W} \quad 120^{\circ} \mathrm{W} \quad 70^{\circ} \mathrm{W} \quad 20^{\circ} \mathrm{W}$

DJF 2010s dry ground uptake

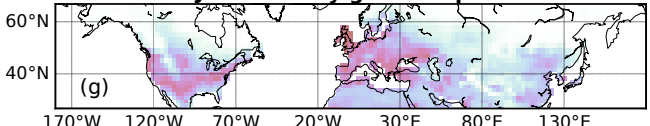

JJA 2010s dry cuticular uptake

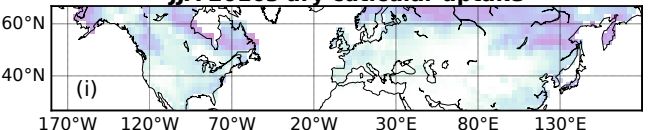

JJA 2010s wet cuticular uptake

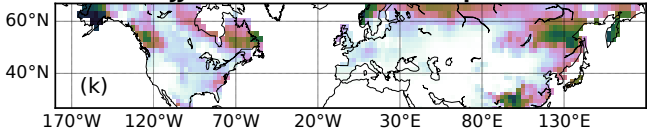

JJA 2010s stomatal uptake

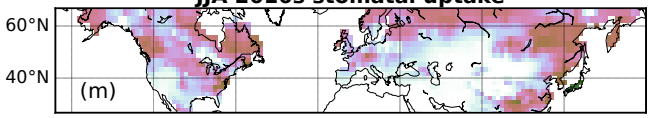

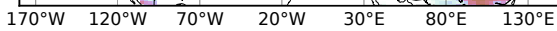

JJA 2010s dry ground uptake

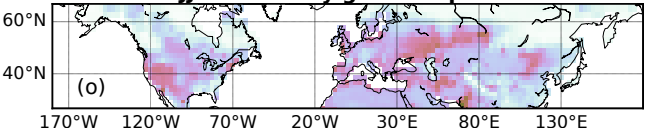

$\begin{array}{lllllll}170^{\circ} \mathrm{W} & 120^{\circ} \mathrm{W} & 70^{\circ} \mathrm{W} & 20^{\circ} \mathrm{W} & 30^{\circ} \mathrm{E} & 80^{\circ} \mathrm{E} & 130^{\circ} \mathrm{E}\end{array}$

$\begin{array}{lllllll}0.0 & 0.1 & 0.2 & 0.3 & 0.4 & 0.5 & 0.6\end{array}$

effective conductance $\left(\mathrm{cm} \mathrm{s}^{-1}\right)$
DJF 2090s-2010s dry and wet cuticular uptake

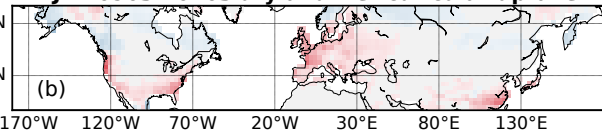

DJF 2090s-2010s stem uptake

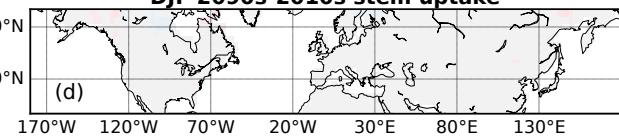

DJF 2090s-2010s snow uptake to cuticles and ground

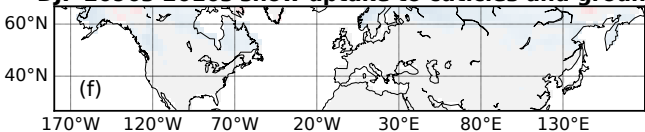

DJF 2090s-2010s dry ground uptake

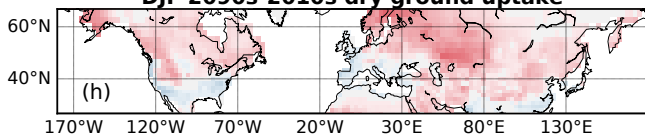

JJA 2090s-2010s dry cuticular uptake

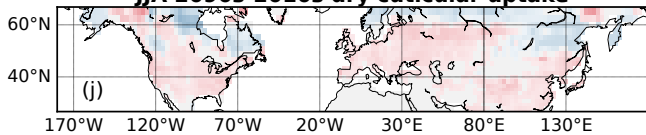

JJA 2090s-2010s wet cuticular uptake

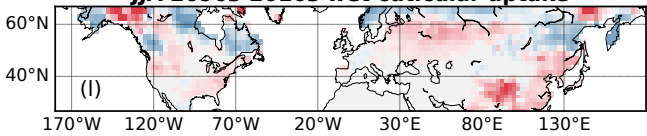

JJA 2090s-2010s stomatal uptake

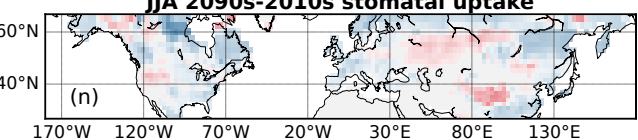

JJA 2090s-2010s dry ground uptake

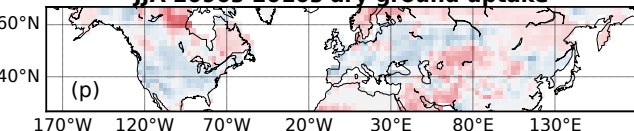

$\begin{array}{lllllll}170^{\circ} \mathrm{W} & 120^{\circ} \mathrm{W} & 70^{\circ} \mathrm{W} & 20^{\circ} \mathrm{W} & 30^{\circ} \mathrm{E} & 80^{\circ} \mathrm{E} & 130^{\circ} \mathrm{E}\end{array}$

$\begin{array}{lllllll}-0.3 & -0.2 & -0.1 & 0.0 & 0.1 & 0.2 & 0.3\end{array}$

change in effective conductance $\left(\mathrm{cm} \mathrm{s}^{-1}\right)$ 
NE US [36-46ㅇ N,70-80 W] SE US [30-38 N,80-95 W] IMW US [36-46 $N, 100-110 \circ$ W]
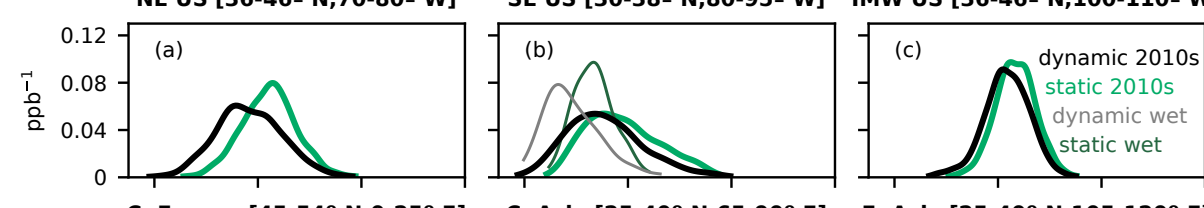

JA 2010s dry-cuticular uptake

C. Europe [45-54 N,0-25 E] C. Asia [25-40 N,65-90 E] E. Asia [25-40 N,105-120 E]
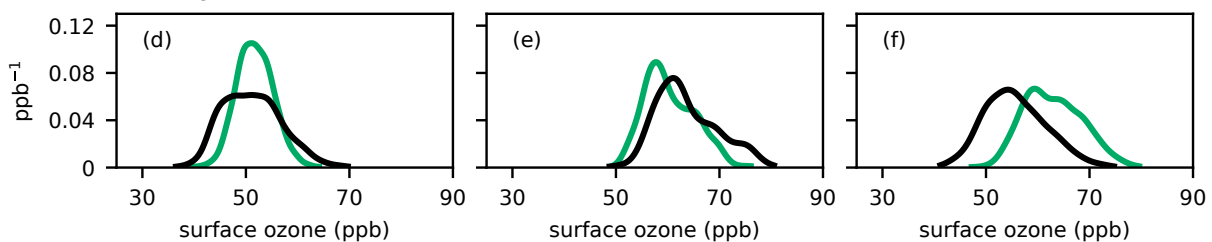

JJA 2010s -r(v $v_{d}$,surface ozone)
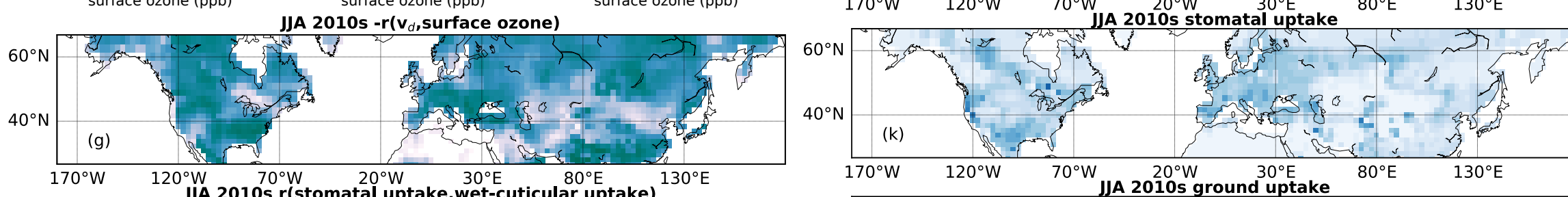
A 2010s r(stomatal uptake, wet-cuticular uptake)
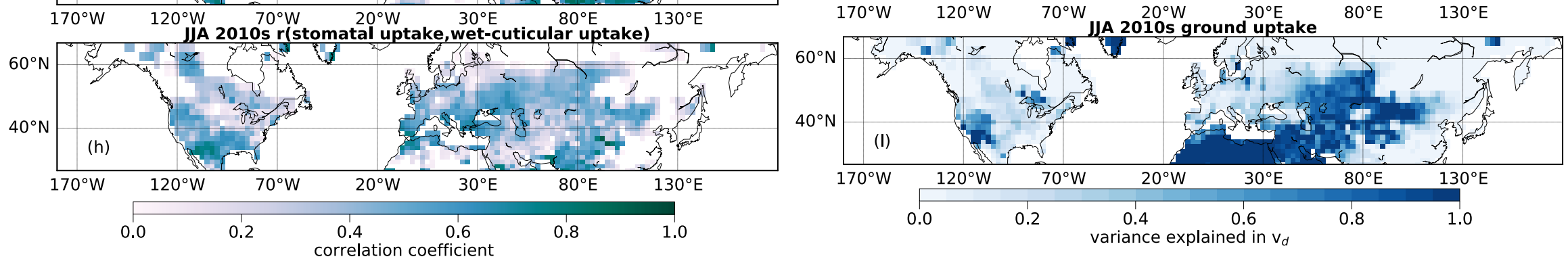